\title{
Initiatives to Promote Access to Medicines After the Publication of National Policy on Comprehensive Care of People With Rare Diseases in Brazil
}

\author{
Cassia Cunico \\ Universidade Federal de Santa Catarina \\ Geison Vicente \\ Universidade Federal de Santa Catarina \\ Silvana Nair Leite ( $\square$ silvana.nair.leite@ufsc.br) \\ Universidade Federal de Santa Catarina
}

\author{
Research Article \\ Keywords: Rare Diseases, Access to medicines, Health policy, Health Technologies, Brazil \\ Posted Date: November 11th, 2021 \\ DOl: https://doi.org/10.21203/rs.3.rs-1000508/v1 \\ License: (1) This work is licensed under a Creative Commons Attribution 4.0 International License. Read Full License
}




\section{Abstract}

\section{Background}

Rare diseases affect a small number of people compared to prevalent diseases' estimates. The vast majority of these diseases are of genetic origin, have no cure, are chronic and can lead to death. Although the right to access to medicines is included in the constitutionally guaranteed right to health in Brazil, problems in the supply of medicines for rare diseases are reported in the country.

\section{Objective}

This study aimed to describe and analyze the initiatives to promote access to medicines for treating rare diseases in Unified Health System, Brazil, after the publication of the National Policy on Comprehensive Care of People with Rare Diseases.

\section{Methods}

Based on the model published by The WHO Regional Office for Europe, which described access to medicines in pre-launch, per-launch and post-launch policies, the initiatives referring to each category were summarized, based on documentary research searched in online databases, in the period from January 2014 to December 2020.

\section{Results}

Different actions and policy interventions were identified, which went through the expansion of resources for research and development, health regulations, incorporation of new drugs, review and publication of clinical guidelines, expansion of the network of care facilities by the Ministry of Health. On the other hand, aspects related to care policies, pricing methods, technological development, and development of pharmaceutical services processes were not implemented.

\section{Conclusions}

Although it is impossible to determine the explicit motivation of such actions concerning the Policy, its publication certainly was a landmark in Brazilian society, allowing greater recognition of the needs of rare diseases patients and the treatment's specificities. However, the study suggests that the steps that make up the life cycle of medicines are not linked, lacking articulation and integration of the care network and, consequently, there is no evidence that the rare diseases policy publication has generated broad impact on the promotion of access to medicines to treat rare diseases in Brazil.

\section{Background}

Rare diseases affect a small number of people compared to prevalent diseases' estimates. However, there is no global consensus regarding its definition, and the prevalence threshold is the most used descriptor ${ }^{1}$.

Individually, these diseases have a low prevalence rate; on the other hand, collectively, they affect a significant percentage of the population. For example, a recent study based on the European definition of rare disease estimated between 6,000 and 8,000 types of rare diseases, affecting at least $3.5-5.9 \%$ of the world population; $71.9 \%$ of those diseases are genetically inherited $69.9 \%$ began to manifest during childhood ${ }^{2}$. The referred study excludes rare cancers, infectious diseases, and poisonings disorders.

In 2014, Brazil published the rare diseases' policy stating that a rare disease is the one that affects up to 65 people per 100,000 inhabitants ${ }^{3}$. In the country, there is an estimated 13 million sufferers from some rare disease ${ }^{4}$.

The National Policy on Comprehensive Care of People with Rare Diseases (PNAIPDR) is organized in structuring axes according to their common characteristics: Axis I - rare genetic diseases and Axis II - rare non-genetic diseases. Among the principles of the PNAIPDR are the incorporation and use of technologies aimed at promotion, prevention, and comprehensive care in the Health Care Network (HCN). Such care includes medicines treatment and nutritional formulas when recommended within the scope of the Brazilian National Health Service, known as the Unified Health System (Portuguese: Sistema Único de Saúde, SUS), whose incorporations should result from the recommendations made by the National Committee for Health Technology Incorporation (CONITEC) and the subsequent drafting of Clinical Guidelines $(\mathrm{PCDT})^{3,5}$. Furthermore, the PNAIPDR proposed two complementary structural components to the HCN: the Specialized Healthcare Center (Serviço de Atenção Especializada) and the Reference Center for Rare Diseases (Serviço de Referência em Doenças Raras). It also created financial incentives for accredited centers and incorporated genetic and biochemical test ${ }^{3}$. 
In the SUS, pharmaceutical service poses a significant challenge for managers and professionals, mainly due to the financial resources involved and the need for technical and organizational improvement. On the one hand, advances in structuring public health policies have allowed greater access to medicines and SUS services; on the other hand, there is still a need for continuous improvements, mainly when sizing the population with specific needs. For example, many sufferers from rare diseases face barriers in accessing care, and a decade ago, less than $10 \%$ received specific treatment for the disease, according to estimates ${ }^{6}$.

In low or middle-income countries, such as Brazil, the availability in the market of medicines for treating rare diseases does not guarantee the patient will have access to them given the gaps in the country's integrated solutions to ensure universal health coverage $\mathrm{e}^{7}$. Some of these gaps pointed out by authors are limited resources and accessibility ${ }^{8,9}$, technological dependence ${ }^{7}$, the inadequacy of metrics in the health technologies assessment $(\mathrm{HTA})^{10}$, the non-incorporation of technology into the public health system ${ }^{11}$ and, the excessive market prices ${ }^{12,13}$.

By the Brazilian Constitution, access to medicines can be understood as part of the right to health. However, not yet overcome problems in medicines provision are broadly reported $8,14,15$, and access to treatment is only possible via legal proceedings ${ }^{8,14}$.

In this sense, this study aims to describe and analyze the initiatives to promote access to medicine for treating rare diseases in the SUS after PNAIPDR publication and implementation.

\section{Methodology}

Based on the model of access to medicines published by The WHO Regional Office for Europe (WHO-Europe 2015) ${ }^{16}$, we summarized initiatives or implementations of political activities according to the life cycle of medicines for treating rare diseases in Brazil from the publication of the PNAIPDR. According to the proposed model, medicines access policies are subdivided into pre-launch, peri-launch, and post-launch activities. In this study, the following actions were analyzed:

- - pre-launch: activities to anticipate and prioritize therapeutic innovation with potential impact on the health system and clinical outcomes. It encompasses research and development, clinical trials, inspection and medicines manufacturing, and horizon scanning.

- - peri-launch: actions related to pricing methods, regulatory mechanisms for marketing authorization, managed-entry agreements, medicines incorporation into health systems.

- - post-launch: procurement, distribution, prescribing, clinical guidelines, dispensing, and pharmacovigilance activities.

For this study, we considered the definition of rare disease according to PNAIPDR ${ }^{3}$. However, this study did not address health conditions such as rare cancers, poisonings disorders. The collected data refer to January 2014 (PNAIPDR enactment date) to December 2020.

The analyzed data are in the public domain and were researched through a documentary assessment on online databases previously defined by the researchers. The sources and searches performed are described in Table 1. 
Table 1

Search about pre-launch, peri-launch and post-launch activities of rare diseases medicines, Brazil, 2014-2020.

Source Digital Repositories Searches

\section{Pre-launch}

National Health Surveillance Agency https://www.gov.br/anvisa/pt(ANVISA)

$\mathrm{br} /$ assuntos/regulamentacao/legislacao

Regulations, standards, procedures, related to research and development, and clinical trials for medicines intended to treat Rare Diseases (RD).

National Committee for Health Technology http://conitec.gov.br/ Incorporation (CONITEC)

Horizon scanning for medicines intended to treat $\mathrm{RD}$.

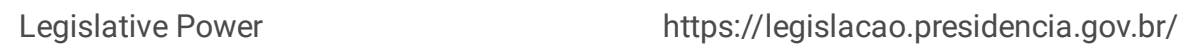

Legislation about therapeutic innovation financing or improve.

Ministry of Health. National Health Council http://conselho.saude.gov.br/resolucoes-cns

Regulations related to research and development, and clinical trials.

Department of Science and Technology of the Secretariat of Science, Technology, and http://pesquisasaude.saude.gov.br

Preclinical and clinical research related to

Strategic Inputs of the Ministry of Health

(Decit/SCTIE/MS) pharmacological therapeutic innovation to treat RD.

Scientific research related to the availability of medicines for RD.

Brazilian Network for Health Technology https://rebrats.saude.gov.br Horizon scanning for Assessment (REBRATS) medicines intended to treat RD.

Brazilian Registry of Clinical Trials (ReBEC) https://ensaiosclinicos.gov.br/

Clinical trials with medicines intended to treat RD.

\section{Peri-launch}

National Health Surveillance Agency (ANVISA) https://www.gov.br/anvisa/pt$\mathrm{br} /$ assuntos/regulamentacao/legislacao $\mathrm{E}$ https://consultas.anvisa.gov.br/\#/medicamentos/

https://www.gov.br/anvisa/pt$\mathrm{br} /$ assuntos/medicamentos/cmed
Regulations, standards, procedures, related to regulatory mechanisms for marketing authorization. Search about rare diseases medicines registered in Brazil.

Medicines Market Regulatory Chamber (CMED)

National Committee for Health Technology http://conitec.gov.br/ Incorporation (CONITEC)

Regulations, standards, procedures, related to pricing methods.

Regulations, standards, procedures, related to health technologies assessment (HTA) for medicines intended to treat RD.

Recommendations for medicines to treat RD.

Ministry of Health. Pharmaceutical Care. https://antigo.saude.gov.br/assistencia-farmaceutica
Legislation related to the availability of new medicines on the national market.

Table of Clinical Situations from Specialized Component of Pharmaceutical Care (CEAF).

Legislation related to the availability of new medicines on the national market. 


\begin{tabular}{|c|c|c|}
\hline Source & Digital Repositories & Searches \\
\hline $\begin{array}{l}\text { Brazilian Network for Health Technology } \\
\text { Assessment (REBRATS) }\end{array}$ & https://rebrats.saude.gov.br & $\begin{array}{l}\text { Improve to teaching, research, } \\
\text { production, dissemination } \\
\text { and use of HTA in Brazil. }\end{array}$ \\
\hline $\begin{array}{l}\text { Ministry of Health. Tripartite Interagency } \\
\text { Commission (CIT) }\end{array}$ & $\begin{array}{l}\text { https://antigo.saude.gov.br/gestao-do-sus/articulacao- } \\
\text { interfederativa/comissao-intergestores- } \\
\text { tripartite/pautas-de-reunioes-e-resumos }\end{array}$ & $\begin{array}{l}\text { Responsible for financing } \\
\text { each medicines that } \\
\text { comprises the incorporated } \\
\text { medicines for RD list. }\end{array}$ \\
\hline \multicolumn{3}{|l|}{ Post-launch } \\
\hline $\begin{array}{l}\text { National Health Surveillance Agency } \\
\text { (ANVISA) }\end{array}$ & $\begin{array}{l}\text { https://www.gov.br/anvisa/pt- } \\
\text { br/assuntos/regulamentacao/legislacao }\end{array}$ & $\begin{array}{l}\text { Regulations, standards, } \\
\text { procedures, related to the } \\
\text { distribution, storage, } \\
\text { transportation, } \\
\text { pharmacosurveillance of } \\
\text { medicines for RD. }\end{array}$ \\
\hline $\begin{array}{l}\text { National Committee for Health Technology } \\
\text { Incorporation (CONITEC) }\end{array}$ & http://conitec.gov.br/ & $\begin{array}{l}\text { New Clinical Guidelines for } \\
\text { RD and its updates. }\end{array}$ \\
\hline Legislative Power & https://legislacao.presidencia.gov.br/ & $\begin{array}{l}\text { Regulation related to the } \\
\text { provision of health services } \\
\text { for RD patients. }\end{array}$ \\
\hline Ministry of Health. Pharmaceutical Care. & https://antigo.saude.gov.br/assistencia-farmaceutica & $\begin{array}{l}\text { Regulation related to } \\
\text { Specialized Component of } \\
\text { Pharmaceutical Care (CEAF). }\end{array}$ \\
\hline $\begin{array}{l}\text { Ministry of Health. National Register of } \\
\text { Health Establishments (CNESNET) }\end{array}$ & $\begin{array}{l}\text { http://cnes2.datasus.gov.br/Mod_Ind_Habilitacoes.asp? } \\
\text { VTipo=H }\end{array}$ & $\begin{array}{l}\text { Reference Services for Rare } \\
\text { Diseases enabled in Brazil. }\end{array}$ \\
\hline $\begin{array}{l}\text { Ministry of Health. Partnership for } \\
\text { Productive Development (PDP) }\end{array}$ & $\begin{array}{l}\text { https://www.gov.br/saude/pt-br/assuntos/saude-de-a- } \\
\text { a-z-1/p/parcerias-para-o-desenvolvimento-produtivo- } \\
\text { pdp }\end{array}$ & $\begin{array}{l}\text { Regulations, standards, } \\
\text { procedures related to national } \\
\text { public medicines } \\
\text { manufacturing. }\end{array}$ \\
\hline $\begin{array}{l}\text { Department of Science and Technology of } \\
\text { the Secretariat of Science, Technology, and } \\
\text { Strategic Inputs of the Ministry of Health } \\
\text { (Decit/SCTIE/MS) }\end{array}$ & http://pesquisasaude.saude.gov.br & $\begin{array}{l}\text { Innovation related to Rational } \\
\text { Use of Medicines (RMU) in } \\
\text { RD. }\end{array}$ \\
\hline Brazilian Registry of Clinical Trials (ReBEC) & https://ensaiosclinicos.gov.br/ & $\begin{array}{l}\text { Clinical trials related to RMU } \\
\text { in RD. }\end{array}$ \\
\hline Source: elaborated by the authors & & \\
\hline
\end{tabular}

Table 1

2.1 Medicines incorporated into the SUS and Clinical Guidelines

A descriptive and exploratory study of the CONITEC recommendations for medicines to treat rare diseases was carried out.

This study considered as a rare disease all those previously mentioned in the Report on Prioritizing Guidelines for Comprehensive Care for People with Rare Diseases in Brazil ${ }^{5}$. Health conditions in which prevalence data are described in CONITEC's recommendation reports and the Ministry of Health (MS) Clinical Protocols conform with the PNAIPDR were also considered. If the cited documents were not clear regarding the rarity of the disease, further search was carried out on the Orphanet website (http://orphanet.net/) for corroboration.

When the technology was demanded more than once for different therapeutic indications, or when a single submission presented two different technologies, they were quantified individually. The recommendations were evaluated according to the active ingredient, clinical indication, the request reason, request agreement (incorporating or not incorporating/changing the Brazilian List of Essential Medicines (RENAME)), applicant type (internal - bodies or institutions linked to the SUS; external - bodies or institutions not connected to the SUS, or individual ), the time elapsed between the proposal submission and the publication of the decision on the recommendation, the time elapsed between the incorporation decision and the publication of the PCDT. The technologies were categorized according to the recommendation decision publication year, with the axes defined by PNAIPDR. This classification was based on the PCDT of each pathology and the Report on Prioritizing Guidelines for Comprehensive Care for People with Rare Diseases in Brazil ${ }^{5}$. 
The list of Clinical Guidelines described in this study was based on the cited report ${ }^{5}$ and updates published on the CONITEC website between January 2014 - December 2020.

The analyzed data are presented as descriptive statistics.

2.2 Responsibility for financing and elapsed time to make medicines available in the SUS

The SUS management sphere responsible for financing each medicines that comprises the roll of incorporated medicines for rare diseases was identified. The searches were carried out in the agendas and summaries of the Tripartite Interagency Commission (CIT) meetings and the Clinical Situations list from the Specialized Component of Pharmaceutical Assistance (CEAF). Their sources are described in Table 1.

Additionally, we also assessed the time elapsed between the incorporation, which occurred during the period of this study, and the medicines provision by SUS, considering two stages:

- - the time elapsed between the proposal submission and the publication by CONITEC of the incorporation decision. To obtain these data, each Report of incorporated medicines for rare diseases was individually evaluated.

- - the time elapsed between CONITEC publication of the incorporation decision and agreement on financing responsibility at CIT. A study of the CIT meetings' agendas and/or summaries was conducted to obtain these data.

The data set obtained were categorized in Microsoft Excel 2016.

\subsection{Legislation/Regulations/Standards}

The legislation/regulations/standards cited in this study were retrieved from a direct search on the electronic addresses quoted in Table 1 and according to the pre-launch, peri-launch, and post-launch policies in Table 2. 
Table 2

- Regulations, norms or guidelines related to rare diseases after PNAIPDR, Brazil, 2014-2020.

\begin{tabular}{|c|c|c|}
\hline Source & Regulation & Content \\
\hline \multicolumn{3}{|l|}{ Pre-launch } \\
\hline \multicolumn{3}{|c|}{ Research, development and clinical trials } \\
\hline \multicolumn{3}{|c|}{ ANVISA $^{a}$} \\
\hline & $\begin{array}{l}\mathrm{RDC}^{\mathrm{b}} 9, \text { of } \\
20 / 02 / 2015\end{array}$ & Regulation for the conduct of clinical trials with medicines in Brazil. \\
\hline & $\begin{array}{l}\text { RDC 449, of } \\
15 / 12 / 2020\end{array}$ & $\begin{array}{l}\text { Amends Article 38, which is related to the Medicines Clinical Development } \\
\text { Dossier; Article } 71 \text { related to inspection, both from RDC 9, of 20/02/2015. }\end{array}$ \\
\hline & $\begin{array}{l}\text { IN }^{\mathrm{C}} 20, \text { of } \\
20 / 10 / 2017\end{array}$ & Good Clinical Practice inspection procedures for clinical medicines trials. \\
\hline & $\begin{array}{l}\text { Guidance } n^{\circ} \\
35 / 2020 \text { - version } \\
1\end{array}$ & $\begin{array}{l}\text { Good Clinical Practice (GCP) inspection guide for clinical trials with } \\
\text { medicines and biological products - Inspection of Clinical Trial Centers. }\end{array}$ \\
\hline & $\begin{array}{l}\text { Guidance } n^{\circ} \\
36 / 2020 \text { - version } \\
1\end{array}$ & $\begin{array}{l}\text { Good Clinical Practice (GCP) inspection guide for clinical trials with } \\
\text { medicines and biological products - Inspection of Sponsors and } \\
\text { Representative Clinical Research Organizations (RCOs). }\end{array}$ \\
\hline & $\begin{array}{l}\mathrm{RDC} 172, \text { of } \\
08 / 09 / 2017\end{array}$ & $\begin{array}{l}\text { Procedures for the import and export of goods and products intended for } \\
\text { scientific or technological research and research involving human beings, and } \\
\text { makes other provisions. }\end{array}$ \\
\hline & $\begin{array}{l}\text { RDC 260, of } \\
21 / 12 / 2018\end{array}$ & $\begin{array}{l}\text { Provides for the rules for conducting clinical trials with investigational } \\
\text { advanced therapy products in Brazil, and makes other provisions. }\end{array}$ \\
\hline & $\begin{array}{l}\text { RDC 311, of } \\
10 / 10 / 2019\end{array}$ & $\begin{array}{l}\text { Amends the RDC } 38 \text {, of } 12 / 08 / 2013 \text {, which approves the regulations for } \\
\text { expanded access programs, compassionate use and post-study medicines } \\
\text { supply. }\end{array}$ \\
\hline \multicolumn{3}{|c|}{$\begin{array}{l}\text { National } \\
\text { Health } \\
\text { Council }\end{array}$} \\
\hline & $\begin{array}{l}\text { Resolução } 563 \text {, of } \\
\text { 10/11/2017 }\end{array}$ & $\begin{array}{l}\text { Regulates the research participant rights to post-study access in clinical } \\
\text { research protocols for patients diagnosed with ultra-rare diseases. }\end{array}$ \\
\hline \multicolumn{3}{|c|}{ Legislative Power } \\
\hline & $\begin{array}{l}\text { Decree } 9283 \text {, of } \\
07 / 02 / 2018\end{array}$ & $\begin{array}{l}\text { Establishes incentives for innovation and scientific and technological } \\
\text { research in the production labs, aiming at technological qualification, the } \\
\text { achievement of technological autonomy, and the development of the national } \\
\text { and regional production system. }\end{array}$ \\
\hline & $\begin{array}{l}\text { Decree } 9245 \text {, of } \\
20 / 12 / 2017\end{array}$ & Establishes the National Policy for Technological Innovation in Health. \\
\hline
\end{tabular}

Source: prepared by the authors based on data obtained from the digital repositories described in Table 1.

$\mathrm{a}=$ National Health Surveillance Agency

$\mathrm{b}=$ Collegiate Board Resolution

${ }^{c}=$ Normative Instruction

$\mathrm{d}=$ Bill in progress in the Chamber of Deputies. Described in the table the one that was approved and awaits conclusive consideration.

e = Brazilian Network for Health Technology Assessment

$\mathrm{f}=$ Minister's Office / Ministry of Health 


\begin{tabular}{|c|c|c|}
\hline Source & Regulation & Content \\
\hline & $\begin{array}{l}\text { Law 13930, of } \\
10 / 12 / 2019\end{array}$ & $\begin{array}{l}\text { Amends the Law 10332, including the forecast of application of at least } 30 \% \\
\text { of the resources from the Program of Incentive to Research in Health for } \\
\text { activities directed to the technological development of medicines, } \\
\text { immunobiologicals, health products and other therapeutic modalities } \\
\text { destined to the treatment of rare or neglected diseases. }\end{array}$ \\
\hline & $\begin{array}{l}\text { Law 13971, of } \\
27 / 12 / 2019\end{array}$ & $\begin{array}{l}\text { It institutes the Multi-Year Plan for the period from } 2020 \text { to } 2023 \text {, proposing } \\
\text { the fostering of scientific and technological research, focused on health care, } \\
\text { including the prevention and treatment of rare diseases. }\end{array}$ \\
\hline & $\begin{array}{l}\text { Decree } 10588 \text {, of } \\
03 / 12 / 2020\end{array}$ & Creates the Interministerial Committee for Rare Diseases \\
\hline
\end{tabular}

\section{Peri-launch}

\section{Market authorization}

ANVISA

RDC 205, of

$28 / 12 / 2017$

RDC 293, of $17 / 07 /$

2019

RDC 204, of

$27 / 12 / 2017$

RDC 338, of

$20 / 02 / 2020$
Establishes special procedures for consent of clinical trials, certification of good manufacturing practices and registration of new medicines for treatment, diagnosis or prevention of rare diseases.

Amends Article19 of RDC 205, which deals with the deadline for the submission of the maximum price definition dossier for the submission of registration applications of new medicines.

Provides on the classification in the priority category of registration, postregistration and prior consent petitions in clinical research of medicines. Article 4 - Frames as priority the petitions related to new therapeutic indication or extension of use intended for rare diseases.

Provides for the registration of advanced therapy products and makes other provisions.

\section{Managed entry}

Ministry
of Health

Ordinance 1297 , of

$11 / 07 / 2019$
Establishes a risk-sharing pilot project for the incorporation of health technologies to provide access to the medicine Nusinersena (Spinraza ${ }^{\circledR}$ ) for the treatment of Spinal Muscular Atrophy (SMA 5q) types II and III within the SUS.

\section{Payment}

Legislative Power Draf Legislation
$3262 / 2020$
Amends the Law 13,930 of 10/12/2019 and creates the National Fund for the Supply of Medicines and Therapies intended for the Treatment of Rare or Neglected Diseases.

\section{Dissemination \\ of HTA}

REBRATS $^{\mathrm{e}}$

Source: prepared by the authors based on data obtained from the digital repositories described in Table 1.

a = National Health Surveillance Agency

$\mathrm{b}=$ Collegiate Board Resolution

${ }^{c}=$ Normative Instruction

$\mathrm{d}=$ Bill in progress in the Chamber of Deputies. Described in the table the one that was approved and awaits conclusive consideration.

e = Brazilian Network for Health Technology Assessment

$\mathrm{f}=$ Minister's Office / Ministry of Health 


\begin{tabular}{|lll|}
\hline Source & Regulation & Content \\
\hline $\begin{array}{l}\text { Ordinance 2575, of } \\
30 / 09 / 2019\end{array}$ & $\begin{array}{l}\text { Provides on the collaborative nature of REBRATS in the scope of the } \\
\text { Secretariat of Science, Technology, Innovation and Strategic Inputs in Health } \\
\text { of the Ministry of Health, with its management under the responsibility of the } \\
\text { Department of Management and Incorporation of Technologies and } \\
\text { Innovation in Health of this Secretariat. }\end{array}$ \\
\hline
\end{tabular}

\section{Pos-launch}

Distribution, storage and transportation of medicines

ANVISA
RDC 304, of
Provides good practice for distribution, storage and transportation of

$17 / 09 / 2019$ medicines.

\section{Financig and execution}

Ministry of Health

Consolidation Ordinance $\mathrm{n}^{\circ}$

$6 / \mathrm{GM} / \mathrm{MS}^{f}$, of $28 / 09 / 2017$

Consolidation Ordinance $\mathrm{n}^{\circ}$

$2 / \mathrm{GM} / \mathrm{MS}$, of

$28 / 09 / 2017$

Ordinance 13, of $06 / 01 / 2020$

Letter $n^{\circ} 9, n^{\circ} 11$ $\mathrm{n}^{\circ} 17 \mathrm{e}$

$37 / 2020 / M S$
Repealed Ordinance MS/GM 1554/2013 that provides on the Financing of the Specialized Component of Pharmaceutical Assistance (CEAF), but there is no change in its contente.

Revoked Ordinance MS/GM 1554/2013 which provides on rules for Financing and Execution of the CEAF, but there is no change in its content.

Changes the rules of Financing and Execution in the CEAF, regarding the 6month validity period, validity and model of the Report for Request,

Evaluation and Authorization of Medicines of the Specialized Component of Pharmaceutical Assistance (LME).

Orientations about the execution of the CEAF in the COVID-19 pandemic scenario.

\section{Pharmacosurveillance}

ANVISA

RDC 406, of

$22 / 07 / 2020$

Provides on the Good Practices of Pharmacosurveillance for Holders of Registration of Medicines for human use, and other provisions.

Services offer

Legislative Power

Decree 10558 , of 03/12/2020

Law 14023, of $08 / 07 / 2020$
Creates the Interministerial Committee for Rare Diseases

Amended Article 3-J of Law 13979, of 06/02/2020, to consider caregivers and attendants of disabled persons, elderly persons or persons with rare diseases as professionals considered essential to the control of diseases and the maintenance of public order, during the public health emergency resulting from the coronavirus responsible for the outbreak of 2019.

Source: prepared by the authors based on data obtained from the digital repositories described in Table 1.

a = National Health Surveillance Agency

$\mathrm{b}=$ Collegiate Board Resolution

${ }^{c}=$ Normative Instruction

$\mathrm{d}=$ Bill in progress in the Chamber of Deputies. Described in the table the one that was approved and awaits conclusive consideration.

e = Brazilian Network for Health Technology Assessment

$\mathrm{f}=$ Minister's Office / Ministry of Health 


\begin{tabular}{|c|c|c|}
\hline Source & Regulation & Content \\
\hline & $\begin{array}{l}\text { Decree } 10174 \text {, of } \\
13 / 12 / 2019\end{array}$ & $\begin{array}{l}\text { Provides for the National Council on the Rights of Persons with Disabilities, } \\
\text { as a higher body of parity, consultative and collegiate deliberation on public } \\
\text { policies for persons with disabilities, established under the Ministry of } \\
\text { Women, Family and Human Rights, providing for the participation of national } \\
\text { organizations related to rare diseases. }\end{array}$ \\
\hline \multicolumn{3}{|l|}{$\begin{array}{l}\text { Ministry } \\
\text { of Health }\end{array}$} \\
\hline & $\begin{array}{l}\text { Ordinance } 3166 \text {, of } \\
03 / 12 / 2019\end{array}$ & Qualifies health establishments as Reference Services in Rare Diseases. \\
\hline & Ordinance 3709 , of & Enables Reference Services for Rare Diseases in the state of São Paulo. \\
\hline & $22 / 12 / 2020$ & \\
\hline & Ordinance 3968 , of & Enables Reference Services for Rare Diseases in the state of Paraná. \\
\hline & $31 / 12 / 2020$ & \\
\hline
\end{tabular}

\section{Partnerships for Productive Development}

Ministry
of Health

Ordinance 2531 , of

12/11/2014,

revoked by

Consolidation

Ordinance $\mathrm{n}^{\circ}$

5/GM/MS, de

28/09/2017

Ordinance 2888 , of

$30 / 12 / 2014$

Ordinance 252 , of

26/01/2017

Ordinance 704 , of 08/03/2017

Decree 10001, of 03/092019
Redefines the guidelines and criteria for defining the list of strategic products for SUS and the establishment of Partnership for Productive Development (PPD). Defines the criteria from the submission of processes, to the monitoring and evaluation of technologies.

Defines the list of strategic products for SUS that are eligible for submission of PPD project proposals in 2015.

Defines the list of strategic products for SUS that are eligible for submission of PPD project proposals for the year 2017, revoking the previous one.

Defines the list of strategic products for SUS that are eligible for submission of PPD project proposals for the year 2017, revoking the previous one.

Provides on the Productive Development Partnerships Deliberative Committee and the Technical Committee for Evaluation of Productive Development Partnerships.

Source: prepared by the authors based on data obtained from the digital repositories described in Table 1.

$\mathrm{a}=$ National Health Surveillance Agency

$\mathrm{b}=$ Collegiate Board Resolution

$\mathrm{c}=$ Normative Instruction

$\mathrm{d}=$ Bill in progress in the Chamber of Deputies. Described in the table the one that was approved and awaits conclusive consideration.

e = Brazilian Network for Health Technology Assessment

$\mathrm{f}=$ Minister's Office / Ministry of Health

\subsection{Rare diseases medicines authorized in the country}

Having the Collegiate Board Resolution (RDC) 205/2017 as a formal framework for pre-market authorization's requests for rare diseases' medicines, research of such medicines registered in Brazil in 2017-2020 was carried out on the National Health Surveillance Agency (ANVISA) website. On the database, all records described in the following regulatory categories: new, biological, specific, and advanced therapy products were individually checked. The gathered data was then categorized in Microsoft Excel 2016.

2.5 Scientific research and clinical trials 
Clinical trials and scientific research related to medicines or nutritional supplementation to treat rare diseases carried out between 2014 to 2020 were searched. To this end, all clinical trial registries included in two repositories were searched: the Brazilian Registry of Clinical Trials (ReBEC) and the Department of Science and Technology of the Secretariat of Science, Technology, and Strategic Inputs of the Ministry of Health (Decit/SCTIE/MS). After individual scans in both repositories, all studies involving new medicines research or improvement/assessment of existing treatments were selected. Finally, the data obtained were quantified and described as textual presentation.

\subsection{Partnerships for Productive Development}

The listings of strategic products to SUS eligible for submitting proposals for Partnership for Productive Development (PDP) projects in 2014-2020 were searched. In addition, the listing of products with partnership in force in December 2020 (research completion date) was also searched and is described in this study.

\subsection{National Reference Services for Rare Diseases}

Based on the code system provided by the legislation, the accredited services to people with rare diseases within the National Register of Health Establishments were searched. First, data concerning the geographic location and types of rare diseases treated for each accredited service were described. Then, the data were categorized in Microsoft Excel 2016.

\section{Results}

Different initiatives were identified in the pre-launch, peri-launch, and post-launch categories from 2014 to 2020 , as described in the text below and in Table 2.

Table 2

\subsection{Pre-launch}

The establishment of the National Policy for Technological Innovation in Health, regulatory procedures related to research involving human beings, and clinical trials with medicines were identified. Furthermore, the methods by which the industry can offer experimental medicines to patients suffering from diseases hitherto untreated in the country were defined, and the right to post-study access to clinical research protocols was granted to patients with ultra-rare diseases.

Regarding rare disease medicines, the National Repository of Clinical Trials (ReBEC) research showed two clinical trials for new medicines, 14 existing pharmacological treatments, and five on food supplementation, either financed by public, private, or mixed capital and having a national or international scope. Moreover, clinical or pre-clinical research registered in Decit/SCTIE/MS totaled 11 studies involving rare diseases, carried out with public funding, and in most cases, under the responsibility of Brazilian universities.

In 2017 an MS investment enabled the construction of the Pharmacological Innovation Laboratory (Laif) at the Federal University of Alagoas (Ufal) aimed at seeking therapeutic alternatives, in particular for Amyotrophic Lateral Sclerosis (ALS).

In addition to these, in 2019, the National Council for Scientific and Technological Development (CNPq), in a partnership with the Ministry of Health (MS), issued a call for research to obtain epidemiological information on rare diseases in Brazil ${ }^{17}$.

The promotion and incentives for research in rare diseases are provided in the 2020-2030 Pluriannual Plan guidelines and the work of the Interministerial Committee on Rare Diseases. In addition, 30\% of the resources destined to the Health Research Promotion Program for the technological development of medicines, immunobiological, health products, and other therapeutic modalities are now allocated to treat rare or neglected diseases (Table 2).

The horizon scanning is being improved in the country as a result of a partnership between Decit/MS and the Biomedical Engineering Program of the Alberto Luiz Coimbra Institute for Graduate Studies and Research in Engineering (COPPE) of the Federal University of Rio de Janeiro (UFRJ) and the Support Program for Institutional Development of the Brazilian Public Health System (PROADI-SUS). Furthermore, a systematic search in the CONITEC website showed that four alerts (2 in 2016, 1 in 2017, 1 in 2018), three reports (2017, 2019, 2020), and 19 sections in recommendation reports of studied medicines (9 in 2018, 6 in 2019 and 4 in 2020) were published while this study was carried on.

3.2 Peri-launch

Page $11 / 29$ 
In Brazil, the sanitary registration of medicines for rare diseases was standardized in 2017 with the publication of the Collegiate Board Resolution (RDC) 205 and its following updates. The swiftness in regulatory processes for rare diseases medicines and the regulatory bases for registering new cellular therapy products, human gene therapy products were also regulated, according to data described in Table 2.

Considering what is described in item 2.4, the medicines for treating rare diseases in Brazil (under this study exclusion criteria) are listed in Table 3. 
Table 3

- Medicines for rare diseases registered aftter RDC ${ }^{a}$ 205/2017, ANVISA ${ }^{\text {b }}$, Brazil, 2017-2020.

\begin{tabular}{|c|c|c|c|c|c|c|}
\hline Medicines & Dosage & Clinical Indication & $\begin{array}{l}\text { Registra- } \\
\text { tion Date }\end{array}$ & $\begin{array}{l}\text { Registra- } \\
\text { tion } \\
\text { Validity }\end{array}$ & $\begin{array}{l}\text { Regulatory } \\
\text { Category }\end{array}$ & $\begin{array}{l}\text { Demanded } \\
\text { to SUSc / } \\
\text { Incorporated } \\
\text { into SUS }\end{array}$ \\
\hline \multirow[t]{2}{*}{ Ocrelizumab } & $30 \mathrm{mg} / \mathrm{mL}$ & Multiple & $26 / 02 / 2018$ & Feb/28 & Biological & Yes/No \\
\hline & & Sclerosis & & & & \\
\hline Nonacog Gamma & $\begin{array}{l}250 \text { Ul; } 500 \\
\text { Ul; } 1000 \text { Ul; } \\
2000 \text { Ul; } \\
3000 \text { UI }\end{array}$ & Hemophilia B & $26 / 02 / 2018$ & Aug/29 & Biological & No/No \\
\hline Agalsidase Beta & $\begin{array}{l}35 \mathrm{mg} / 20 \\
\mathrm{~mL}\end{array}$ & Fabry Disease & $30 / 04 / 2018$ & Apr/20 & Biological & Yes/No \\
\hline Cerliponase Alfa & $30 \mathrm{mg} / \mathrm{mL}$ & $\begin{array}{l}\text { Neuronal Ceroid } \\
\text { Lipofuscinosis Type } 2\end{array}$ & $16 / 07 / 2018$ & $\mathrm{Jul} / 28$ & Biological & No/No \\
\hline Emicizumab & $\begin{array}{l}30 \mathrm{mg} / \mathrm{mL} ; \\
60 \\
\mathrm{mg} / 0,4 \mathrm{~mL} ; \\
105 \\
\mathrm{mg} / 0,7 \mathrm{~mL} ; \\
150 \mathrm{mg} / \mathrm{mL}\end{array}$ & Hemophilia A & $16 / 07 / 2018$ & Jul /28 & Biological & Yes/Yes \\
\hline Ivacaftor+Lumacaftor & $\begin{array}{l}125 \mathrm{mg}+100 \\
\mathrm{mg} ; 125 \\
\mathrm{mg}+200 \mathrm{mg}\end{array}$ & Cystic Fibrosis & 23/07/2018 & Jul /23 & New & Yes/No \\
\hline Ivacaftor & $150 \mathrm{mg}$ & Cystic Fibrosis & 03/09/2018 & Sep/23 & New & Yes/Yes \\
\hline Albutrepenonacog Alfa & $\begin{array}{l}250 \text { Ul; } 500 \\
\text { Ul; } 1000 \text { Ul; } \\
2000 \text { Ul; }\end{array}$ & Hemophilia B & 08/10/2018 & Oct/28 & Biological & No/No \\
\hline Vestronidase Alfa & $10 \mathrm{mg} / 5 \mathrm{~mL}$ & $\begin{array}{l}\text { Mucopolysaccharidosis } \\
\text { VII }\end{array}$ & $15 / 10 / 2018$ & Oct/28 & Biological & Yes/Yes \\
\hline Defibrotide & $80 \mathrm{mg} / \mathrm{mL}$ & $\begin{array}{l}\text { Liver Veno-Occlusive } \\
\text { Disease }\end{array}$ & $11 / 03 / 2019$ & Mar/29 & Biological & No/No \\
\hline Burosumab & $20 \mathrm{mg} / \mathrm{mL}$ & $\begin{array}{l}\text { X-Linked } \\
\text { Hipophosphatemia in } \\
\text { adults and children (age } \\
>1 \text { years old) }\end{array}$ & 25/03/2019 & Mar/29 & Biological & Yes/No \\
\hline Ataluren & $\begin{array}{l}125 \mathrm{mg} ; 250 \\
\mathrm{mg} ; 1000 \\
\mathrm{mg}\end{array}$ & $\begin{array}{l}\text { Duchenne Muscular } \\
\text { Dystrophy }\end{array}$ & $29 / 04 / 2019$ & Apr /29 & New & No/No \\
\hline Selexipag & $\begin{array}{l}0,2 \text { mg; 0,4 } \\
\text { mg; 0,6 mg; } \\
0,8 \text { mg; } 1 \\
\text { mg; } 1,2 \text { mg; } \\
1,6 \text { mg }\end{array}$ & $\begin{array}{l}\text { Pulmonary Arterial } \\
\text { Hypertension }\end{array}$ & $29 / 04 / 2019$ & Jan/28 & New & $\begin{array}{l}\text { Yes/Under } \\
\text { review }\end{array}$ \\
\hline Carglumic Acid & $200 \mathrm{mg}$ & Hyperammo-nemia & 10/06/2019 & Jun/29 & New & No/No \\
\hline
\end{tabular}

Source: Prepared by the authors based on data from the digital repositories of National Health Surveillance Agency (ANVISA) and National Committee for Health Technology Incorporation (CONITEC).

$\mathrm{a}=$ Collegiate Board Resolution

$\mathrm{b}=$ National Health Surveillance Agency

${ }^{c}=$ Unified Health System

$\mathrm{d}=$ viral genome $/ \mathrm{mL}$

Search corresponds to the period $01 / 12 / 2017$ to $31 / 12 / 2020$.

Page 13/29 


\begin{tabular}{|c|c|c|c|c|c|c|}
\hline Medicines & Dosage & Clinical Indication & $\begin{array}{l}\text { Registra- } \\
\text { tion Date }\end{array}$ & $\begin{array}{l}\text { Registra- } \\
\text { tion } \\
\text { Validity }\end{array}$ & $\begin{array}{l}\text { Regulatory } \\
\text { Category }\end{array}$ & $\begin{array}{l}\text { Demanded } \\
\text { to SUS }{ }^{c} / \\
\text { Incorporated } \\
\text { into SUS }\end{array}$ \\
\hline Hemin & $350 \mathrm{mg}$ & $\begin{array}{l}\text { Acute Intermittent } \\
\text { Porphyria }\end{array}$ & 19/08/2019 & Aug/29 & Biological & No/No \\
\hline Ravulizumab & $10 \mathrm{mg} / \mathrm{mL}$ & $\begin{array}{l}\text { Paroxistic Nocturnal } \\
\text { Hemoglobinuria }\end{array}$ & 02/09/2019 & Sep/29 & Biological & No/No \\
\hline Betaine & $1 \mathrm{~g} / \mathrm{g}$ & Homocystinuria & 09/09/2019 & Sep/24 & Specific & No/No \\
\hline Nitisinone & $\begin{array}{l}2 \mathrm{mg} ; 5 \mathrm{mg} \\
10 \mathrm{mg} ; 20 \\
\mathrm{mg}\end{array}$ & $\begin{array}{l}\text { Hereditary Type } 1 \\
\text { Tyrosinemia }\end{array}$ & 07/10/2019 & Oct/24 & New & No/No \\
\hline Inotersen & $200 \mathrm{mg} / \mathrm{mL}$ & $\begin{array}{l}\text { Polyneuropathy caused } \\
\text { by Hereditary } \\
\text { Transthyretin-mediated } \\
\text { Amyloidosis }\end{array}$ & 29/10/2019 & Oct/24 & New & No/No \\
\hline Migalastat & $123 \mathrm{mg}$ & Fabry Disease & $02 / 12 / 2019$ & $\mathrm{Dec} / 24$ & New & $\begin{array}{l}\text { Yes/Under } \\
\text { review }\end{array}$ \\
\hline Lonoctocog Alfa & $\begin{array}{l}250 \mathrm{Ul} ; 500 \\
\text { Ul; } 1000 \mathrm{Ul} ; \\
2000 \mathrm{Ul} ; \\
3000 \mathrm{UI}\end{array}$ & Hemophilia A & $02 / 12 / 2019$ & $\mathrm{Dec} / 29$ & Biological & No/No \\
\hline Octocogue Beta & $\begin{array}{l}250 \mathrm{Ul} ; 500 \\
\text { Ul; } 1000 \mathrm{Ul} ; \\
2000 \mathrm{Ul} ; \\
3000 \mathrm{UI}\end{array}$ & Hemophilia A & $06 / 01 / 2020$ & Jan/30 & Biological & No/No \\
\hline (Tezacaftor/lvacaftor)+Ivacaftor & $\begin{array}{l}(100 \\
\mathrm{mg} / 150 \\
\mathrm{mg})+150 \\
\mathrm{mg}\end{array}$ & Cystic Fibrosis & $27 / 01 / 2020$ & Jan/23 & New & No/No \\
\hline Damoctocog Alfa Pegol & $\begin{array}{l}500 \text { Ul; } 1000 \\
\text { Ul; } 20000 \mathrm{Ul} ; \\
3000 \mathrm{UI}\end{array}$ & Hemophilia A & $17 / 02 / 2020$ & $\mathrm{Feb} / 30$ & Biological & $\begin{array}{l}\text { Yes/Under } \\
\text { review }\end{array}$ \\
\hline Patisiran & $2 \mathrm{mg} / \mathrm{mL}$ & $\begin{array}{l}\text { Polyneuropathy in } \\
\text { Hereditary Transthyretin- } \\
\text { mediated Amyloidosis } \\
\text { (hATTR amyloidosis) }\end{array}$ & $26 / 02 / 2020$ & $\mathrm{Feb} / 23$ & New & No/No \\
\hline Crizanlizumab & $10 \mathrm{mg} / \mathrm{mL}$ & $\begin{array}{l}\text { Vaso-occlusive crisis in } \\
\text { Sickle Cell Anemia }\end{array}$ & $02 / 03 / 2020$ & Mar/23 & Biological & No/No \\
\hline Velmanase Alfa & $10 \mathrm{mg}$ & Alpha-mannosidosis & $06 / 04 / 2020$ & Apr/23 & Biological & Não/Não \\
\hline Givosiran & $189 \mathrm{mg} / \mathrm{mL}$ & $\begin{array}{l}\text { Acute Hepatic Porphyria } \\
\text { in adults }\end{array}$ & $20 / 07 / 2020$ & $\mathrm{Jul} / 23$ & New & No/No \\
\hline Voretigene Neparvovec & $\begin{array}{l}5,0 \times 10^{12} \\
\mathrm{gv} / \mathrm{mL}^{\mathrm{d}}\end{array}$ & $\begin{array}{l}\text { Inherited Retinal } \\
\text { Dystrophies }\end{array}$ & $06 / 08 / 2020$ & Aug/25 & $\begin{array}{l}\text { Advanced } \\
\text { Therapy } \\
\text { Products }\end{array}$ & No/No \\
\hline
\end{tabular}

Source: Prepared by the authors based on data from the digital repositories of National Health Surveillance Agency (ANVISA) and National Committee for Health Technology Incorporation (CONITEC).

$\mathrm{a}=$ Collegiate Board Resolution

$\mathrm{b}=$ National Health Surveillance Agency

${ }^{c}=$ Unified Health System

$\mathrm{d}=$ viral genome $/ \mathrm{mL}$

Search corresponds to the period 01/12/2017 to 31/12/2020. 


\begin{tabular}{|c|c|c|c|c|c|c|}
\hline Medicines & Dosage & Clinical Indication & $\begin{array}{l}\text { Registra- } \\
\text { tion Date }\end{array}$ & $\begin{array}{l}\text { Registra- } \\
\text { tion } \\
\text { Validity }\end{array}$ & $\begin{array}{l}\text { Regulatory } \\
\text { Category }\end{array}$ & $\begin{array}{l}\text { Demanded } \\
\text { to SUS }{ }^{c} / \\
\text { Incorporated } \\
\text { into SUS }\end{array}$ \\
\hline $\begin{array}{l}\text { Onasemnogene Abeparvovec- } \\
\text { xioi }\end{array}$ & $\begin{array}{l}2,0 \times 10^{13} \\
\mathrm{gv} / \mathrm{mL}\end{array}$ & $\begin{array}{l}\text { Spinal Muscular Atrophy } \\
\text { (SMA) }\end{array}$ & $17 / 08 / 2020$ & Aug/25 & $\begin{array}{l}\text { Advanced } \\
\text { Therapy } \\
\text { Products }\end{array}$ & No/No \\
\hline Rurioctocog Alfa Pegol & $\begin{array}{l}250 \text { Ul; } 500 \\
\text { Ul; } 750 \mathrm{Ul} ; \\
1000 \mathrm{Ul} ; \\
1500 \mathrm{Ul} ; \\
2000 \mathrm{Ul} ; \\
3000 \mathrm{UI}\end{array}$ & Hemophilia A & $28 / 09 / 2020$ & Jan/30 & Biological & $\begin{array}{l}\text { Yes/Under } \\
\text { review }\end{array}$ \\
\hline Teduglutide & $5 \mathrm{mg}$ & Short Bowel Syndrome & $28 / 09 / 2020$ & Nov/28 & Biological & No/No \\
\hline Agalsidase Alfa & $1 \mathrm{mg} / \mathrm{mL}$ & Fabry Disease & $28 / 09 / 2020$ & $\mathrm{Jul} / 29$ & Biological & Yes/No \\
\hline Lanadelumab & $150 \mathrm{mg} / \mathrm{mL}$ & $\begin{array}{l}\text { Hereditary Angioedema } \\
\text { (HAE) }\end{array}$ & $28 / 09 / 2020$ & Oct $/ 29$ & Biological & $\begin{array}{l}\text { Yes/Under } \\
\text { review }\end{array}$ \\
\hline Risdiplam & $0,75 \mathrm{mg} / \mathrm{mL}$ & $\begin{array}{l}\text { Spinal Muscular Atrophy } \\
\text { (SMA) }\end{array}$ & $13 / 10 / 2020$ & Oct $/ 23$ & New & $\begin{array}{l}\text { Yes/Under } \\
\text { review }\end{array}$ \\
\hline Lomitapide & $\begin{array}{l}5 \mathrm{mg} ; 10 \mathrm{mg} ; \\
20 \mathrm{mg}\end{array}$ & $\begin{array}{l}\text { Homozygous Familial } \\
\text { Hypercholesterolemia }\end{array}$ & $07 / 12 / 2020$ & $\mathrm{Dec} / 23$ & New & No/No \\
\hline Satralizumab & $120 \mathrm{mg} / \mathrm{mL}$ & $\begin{array}{l}\text { Neuromyelitis Optica } \\
\text { Spectrum Disorder }\end{array}$ & $21 / 12 / 2020$ & $\mathrm{Dec} / 30$ & Biological & No/No \\
\hline \multicolumn{7}{|c|}{$\begin{array}{l}\text { Source: Prepared by the authors based on data from the digital repositories of National Health Surveillance Agency (ANVISA) and } \\
\text { National Committee for Health Technology Incorporation (CONITEC). }\end{array}$} \\
\hline \multicolumn{7}{|l|}{$\mathrm{a}=$ Collegiate Board Resolution } \\
\hline \multicolumn{7}{|c|}{$\mathrm{b}=$ National Health Surveillance Agency } \\
\hline \multicolumn{7}{|l|}{${ }^{c}=$ Unified Health System } \\
\hline \multicolumn{7}{|l|}{$\mathrm{d}=$ viral genome $/ \mathrm{mL}$} \\
\hline Search corresponds to the peri & $12 / 2017$ to & 12/2020. & & & & \\
\hline
\end{tabular}

Table 3

Regarding HTA, no specified and validated criteria for the rare disease were identified. The Brazilian Network for Health Technology Assessment (REBRATS) held several events: discussion on Multicriteria Decision Analysis (MCDA) in HTA; workshop in partnership with The National Institute for Health and Care Excellence (NICE) to address methodological aspects of HTA and strategies for the involvement of patients, industry sectors, and other stakeholders; and a congress on patient involvement in the HTA process.

In October 2020, CONITEC launched on its website an area designed for the public and patient involvement called Patient's Perspective (Perspectiva do Paciente), where patients or caregivers can write about their experiences concerning the disease they are facing. In addition, rare diseases were the subject of two public calls for medicines analysis between October and December 2020.

Incorporation requests of medicines for rare diseases were the most frequent $(n=64)$. Requests for amendments in the Brazilian List of Essential Medicines (RENAME), such as expansion, restriction, and withdrawal, were identified $(n=16)$. As to medicines incorporation requests, the external applicants submitted most proposals (pharmaceutical industry: $n=40,62.5 \%$ and judicial branch: $n=1,1.6 \%$ ), whereas the internal applicant (MS) submitted 23 requests (35.9\%). There was agreement in the recommendations in 32 decisions; 18 (56.3\%) were requests from the external applicant and $14(43.8 \%)$ from the internal applicant. The incorporation or non-incorporation recommendations are described in Table 4. 
- Recommendations obtained from CONITEC according to the year of publication, Brazil, 2014 - 2020.

\begin{tabular}{|c|c|c|c|}
\hline Year & Clinical Indication & Medicines & Recommendation \\
\hline \multicolumn{4}{|c|}{ Rare Genetic Diseases (Axis I)* } \\
\hline \multicolumn{4}{|c|}{2014} \\
\hline & Gaucher Disease & Alfataliglicerace & Incorporation \\
\hline \multicolumn{4}{|c|}{2015} \\
\hline & Hereditary Angioedema & Icatibant & $\begin{array}{l}\text { Non- } \\
\text { incorporation }\end{array}$ \\
\hline & Sickle Cell Disease & Erythropoietin & $\begin{array}{l}\text { Non- } \\
\text { incorporation }\end{array}$ \\
\hline & Congenital Adrenal Hyperplasia & Hydrocortisone 10mg & Incorporation \\
\hline & Congenital Adrenal Hyperplasia & Hydrocortisone 20mg & Incorporation \\
\hline \multicolumn{4}{|c|}{2016} \\
\hline & Cystic Fibrosis & Tobramycin & Incorporation \\
\hline \multicolumn{4}{|c|}{2017} \\
\hline & Hemophilia B (age < 19 years old) & Nonacog Alfa & $\begin{array}{l}\text { Non- } \\
\text { incorporation }\end{array}$ \\
\hline & Mucopolysaccharidosis I & Laronidase & Incorporation \\
\hline & Mucopolysaccharidosis II & Idursulfase & Incorporation \\
\hline \multicolumn{4}{|c|}{2018} \\
\hline & Fabry Disease & Agalsidase Alfa & $\begin{array}{l}\text { Non- } \\
\text { incorporation }\end{array}$ \\
\hline & Fabry Disease & Agalsidase Beta & $\begin{array}{l}\text { Non- } \\
\text { incorporation }\end{array}$ \\
\hline & Phenylketonuria & Sapropterin & Incorporation \\
\hline & Paroxistic Nocturnal Hemoglobinuria & Eculizumab & Incorporation \\
\hline & Homozygous Familial Hypercholesterolemia & Evolucumab & $\begin{array}{l}\text { Non- } \\
\text { incorporation }\end{array}$ \\
\hline & Mucopolysaccharidosis IVa & Elosulfase Alfa & Incorporation \\
\hline & Mucopolysaccharidosis VI & Galsulfase & Incorporation \\
\hline & Familial Amyloid Polyneuropathy & Tafamidis & Incorporation \\
\hline \multicolumn{4}{|c|}{2019} \\
\hline & 5q Spinal Muscular Atrophy - type 1* & Nusinersen & Incorporation \\
\hline & Pompe Disease & Alglucosidase Alfa & Incorporation \\
\hline & Niemann-Pick tipo C Disease & Miglustat & $\begin{array}{l}\text { Non- } \\
\text { incorporation }\end{array}$ \\
\hline & Paroxistic Nocturnal Hemoglobinuria & $\begin{array}{l}\text { Meningococcal Conjugate } \\
\text { Vacines ACWY }\end{array}$ & Incorporation \\
\hline & Paroxistic Nocturnal Hemoglobinuria & $\begin{array}{l}\text { Meningococcal B Vacines } \\
\text { (Recombinant) }\end{array}$ & $\begin{array}{l}\text { Non- } \\
\text { incorporation }\end{array}$ \\
\hline
\end{tabular}

Source: Prepared by the authors based on data from the digital repositories of National Committee for Health Technology Incorporation (CONITEC).

* Axis according Ordinance $n^{\circ} 199,2014^{3}$. 


\begin{tabular}{|c|c|c|c|}
\hline Year & Clinical Indication & Medicines & Recommendation \\
\hline & Hemophilia A with factor VIII inhibitor & Emicizumab & Incorporation \\
\hline & Hemophilia A & Eftrenonacog Alfa & $\begin{array}{l}\text { Non- } \\
\text { incorporation }\end{array}$ \\
\hline & Hemophilia B & Eftrenonacog Alfa & $\begin{array}{l}\text { Non- } \\
\text { incorporation }\end{array}$ \\
\hline & Classical Homocystinuria & $\begin{array}{l}\text { Methionine free metabolic } \\
\text { formula }\end{array}$ & Incorporation \\
\hline & Atypical Hemolytic Uremic Syndrome & Eculizumabe & $\begin{array}{l}\text { Non- } \\
\text { incorporation }\end{array}$ \\
\hline \multicolumn{4}{|l|}{2020} \\
\hline & Cystic Fibrosis & Ivacaftor & Incorporation \\
\hline & Congenital Hypothyroidism & Levothyroxine & Incorporation \\
\hline & Mucopolysaccharidosis VII & Vestronidase Alfa & Incorporation \\
\hline \multicolumn{4}{|c|}{ Rare Non-Genetics Disease (Axis II)* } \\
\hline \multicolumn{4}{|l|}{2014} \\
\hline & Multiple Sclerosis & Fingolimod & Incorporation \\
\hline \multicolumn{4}{|l|}{2015} \\
\hline & Acromegaly & Pegvisomant & $\begin{array}{l}\text { Non- } \\
\text { incorporation }\end{array}$ \\
\hline \multicolumn{4}{|l|}{2016} \\
\hline & Ankylosing Spondylitis & Golimumab & Incorporation \\
\hline & Relapsing-remitting Multiple Sclerosis & Dimethyl Fumarate & $\begin{array}{l}\text { Non- } \\
\text { incorporation }\end{array}$ \\
\hline \multicolumn{4}{|l|}{2017} \\
\hline & Crohn's Disease & Certulizumab & Incorporation \\
\hline & Relapsing-remitting Multiple Sclerosis & Fingolimod & Incorporation \\
\hline & Relapsing-remitting Multiple Sclerosis & Dimethyl Fumarate & Incorporation \\
\hline & Relapsing-remitting Multiple Sclerosis & Teriflunomide & Incorporation \\
\hline & Relapsing-remitting Multiple Sclerosis & Aletumzumab & $\begin{array}{l}\text { Non- } \\
\text { incorporation }\end{array}$ \\
\hline \multicolumn{4}{|l|}{2018} \\
\hline & Primary Biliary Cholangitis & Ursodeoxycholic Acid & Incorporation \\
\hline & Paget's Disease & Zoledronic Acid & Incorporation \\
\hline & Relapsing-remitting Multiple Sclerosis & Glatiramer $40 \mathrm{mg}$ & Incorporation \\
\hline & Ankylosing spondylitis & Secukinumab & Incorporation \\
\hline & Idiopathic Thrombocytopenic Purpura & Eltrombopag Olamine & Incorporation \\
\hline & $\begin{array}{l}\text { Non-infectious Intermediate Uveitis, Posterior Uveitis and Active } \\
\text { Panuveitis }\end{array}$ & Adalimumab & Incorporation \\
\hline
\end{tabular}

Source: Prepared by the authors based on data from the digital repositories of National Committee for Health Technology Incorporation (CONITEC).

* Axis according Ordinance $n^{\circ} 199,2014^{3}$. 


\begin{tabular}{|c|c|c|c|}
\hline Year & Clinical Indication & Medicines & Recommendation \\
\hline & Relapsing-remitting Multiple Sclerosis & Alentuzumab & $\begin{array}{l}\text { Non- } \\
\text { incorporation }\end{array}$ \\
\hline & Idiopathic Pulmonary Fibrosis & Nintedanib & $\begin{array}{l}\text { Non- } \\
\text { incorporation }\end{array}$ \\
\hline & Idiopathic Pulmonary Fibrosis & Pirfenidone & $\begin{array}{l}\text { Non- } \\
\text { incorporation }\end{array}$ \\
\hline & Inoperable Chronic Thromboembolic Pulmonary Hypertension & Riociguat & $\begin{array}{l}\text { Non- } \\
\text { incorporation }\end{array}$ \\
\hline & Systemic Lupus Erythematosus & Belimumab & $\begin{array}{l}\text { Non- } \\
\text { incorporation }\end{array}$ \\
\hline & Idiopathic Thrombocytopenic Purpura & Romiplostim & $\begin{array}{l}\text { Non- } \\
\text { incorporation }\end{array}$ \\
\hline & $\begin{array}{l}\text { Non-infectious Intermediate Uveitis, Posterior Uveitis and Inactive } \\
\text { Panuveitis }\end{array}$ & Adalimumab & $\begin{array}{l}\text { Non- } \\
\text { incorporation }\end{array}$ \\
\hline \multicolumn{4}{|l|}{2019} \\
\hline & Relapsing-remitting Multiple Sclerosis & Dimethyl Fumarate & Incorporation \\
\hline & Juvenile Idiopathic Arthritis & Canakinumab & $\begin{array}{l}\text { Non- } \\
\text { incorporation }\end{array}$ \\
\hline & Crohn's Disease & Vendolizumab & $\begin{array}{l}\text { Non- } \\
\text { incorporation }\end{array}$ \\
\hline & Relapsing-remitting Multiple Sclerosis & Ocrelizumab & $\begin{array}{l}\text { Non- } \\
\text { incorporation }\end{array}$ \\
\hline & Progressive Multiple Sclerosis & Ocrelizumab & $\begin{array}{l}\text { Non- } \\
\text { incorporation }\end{array}$ \\
\hline & $\begin{array}{l}\text { Inoperable Chronic Thromboembolic Pulmonary Hypertension or } \\
\text { recurrent after surgery }\end{array}$ & Riociguat & $\begin{array}{l}\text { Non- } \\
\text { incorporation }\end{array}$ \\
\hline & Ankylosing Spondylitis & Secukinumab & $\begin{array}{l}\text { Non- } \\
\text { incorporation }\end{array}$ \\
\hline \multicolumn{4}{|c|}{$\begin{array}{l}\text { Source: Prepared by the authors based on data from the digital repositories of National Committee for Health Technology Incorporation } \\
\text { (CONITEC). }\end{array}$} \\
\hline \multicolumn{4}{|c|}{ * Axis according Ordinance $n^{\circ} 199,2014^{3}$. } \\
\hline
\end{tabular}

Table 4

To obtain the 32 incorporation recommendations, the time elapsed to achieve a result was 233 days (median; $n=32$; minimum time $=49$ days; maximum time $=607$ days), complying with the law ${ }^{18}$. The maximum time observed referred to the methionine-free metabolic formula for classical homocystinuria.

In Brazil, in 2018, some incorporation recommendations of medicines for rare diseases (nusinersen, eculizumab, galsulfase, elosulfase alfa) started to require patients' follow-up in reference centers to collect evidence of the clinical effectiveness in real-world situations. Then, within three years, a subsequent reassessment by CONITEC should be carried out, which in the reports is called ad experimentum use reports.

An innovative approach to financing the purchase occurred in April 2019, when the MS decided to incorporate nusinersen for spinal muscular atrophy (5q SMA) type 2 and 3 through a risk-sharing agreement. This project was an alternative measure to produce additional evidence about the therapeutic value of this medicines and observe the real impacts on patients' health and quality of life. However, this agreement failed due to the lack of detailed regulations and legal standards for implementation within SUS scope ${ }^{19}$.

A bill related to the costing and supply of medicines and therapies for treating rare or neglected diseases is in progress in the Chamber of Deputies and awaits conclusive consideration (Table 2).

\subsection{Post-launch}


It was identified that CONITEC made public and patient involvement possible through a poll (Enquete) to discuss aspects in the initial phase of PCDT drafting. During the period of this study, four polls addressed rare diseases.

Prior to the PNAIPDR, there were 35 PCDT for rare diseases in the SUS scope. The strategy defined for implementing the PNAIPDR was convening an expert panel to establish criteria and priorities for drafting further PCDT ${ }^{5}$.

Thirty-one PCDT for rare diseases were updated, and 16 new ones were implemented, totaling 51 PCDT (Table 5). 
Table 5

- Clinical guidelines for rare diseases, Brazil, 2014-2020.

\section{CLINICAL GUIDELINES}

\section{Before PNAIPDR}

Acromegaly

Aplastic Anemia, Myelodysplasia and Constitutional Neutropenias

Autoimmune Hemolytic Anemia

Hereditary Angioedema

Acquired Chronic Pure Red Cell Aplasia

Juvenile Idiopathic Arthritis

Reactive Arthritis - Reiter's Syndrome

5q Spinal Muscular Atrophy - type 1*

Primary Biliary Cholangitis*

Biotinidase Deficiency

Hypopituitarism

Dermatomyositis and Polymyositis

Diabetes Insipidus

Focal Dystonias and Hemifacial Spasm

Crohn's Disease

Gaucher Disease

Paget's Disease

Pompe Disease*

Wilson Disease

\begin{tabular}{|c|c|}
\hline & Updated \\
\hline $\begin{array}{l}\text { Ordinance SAS/MS }{ }^{a} n^{\circ} \\
199-25 / 02 / 2013\end{array}$ & $\begin{array}{l}\text { Joint Ordinance } \mathrm{n}^{\circ} 02- \\
\text { 07/01/2019 }\end{array}$ \\
\hline $\begin{array}{l}\text { Ordinance SAS/MS no } \\
212-23 / 04 / 2010\end{array}$ & $\begin{array}{l}\text { Ordinance SAS/MS n }{ }^{\circ} 113 \\
-04 / 02 / 2016\end{array}$ \\
\hline
\end{tabular}

$212-23 / 04 / 2010$

- 04/02/2016
New

Joint Ordinance $\mathrm{n}^{\circ} 27$ $26 / 11 / 2018$

Ordinance SAS/MS n ${ }^{\circ} 880$

- 12/07/2016

Ordinance SAS/MS n ${ }^{\circ} 449$

- 29/04/2016
Joint Ordinance $\mathrm{n}^{\circ} 14$ $31 / 08 / 2020$ $\begin{array}{ll}\text { Ordinance SAS/MS n } & \\ 207-23 / 04 / 2010 & \text { Ordinance SAS/MS n } \\ & \\ 207 & 1.150-11 / 11 / 2015\end{array}$

$\begin{array}{ll}\text { Ordinance SAS/MS n } & \\ 207-23 / 04 / 2010 & \text { Ordinance SAS/MS n } \\ & 1.150-11 / 11 / 2015\end{array}$ $207-23 / 04 / 2010$
Joint Ordinance SAS/SCTIE $\mathrm{n}^{\circ}$ $15-22 / 10 / 2019$

Joint Ordinance $\mathrm{n}^{\circ} 11$ 09/09/2019

Joint Ordinance $\mathrm{n}^{\circ} 13$ 04/05/2018
Ordinance SAS/MS n ${ }^{\circ} \quad$ Joint Ordinance $\mathrm{n}^{\circ} 28$ $110-10 / 05 / 2010$

Ordinance SAS/MS $\mathrm{n}^{\circ}$ $206-23 / 04 / 2010$

Ordinance SAS/MS $\mathrm{n}^{\circ}$ $710-17 / 12 / 2010$

Ordinance SAS/MS $\mathrm{n}^{\circ}$ $376-10 / 11 / 2009$

Ordinance SAS/MS n ${ }^{\circ}$ $711-17 / 12 / 2010$

Ordinance SAS/MS $\mathrm{n}^{\circ}$ $708-25 / 10 / 2011$

Ordinance SAS/MS $\mathrm{n}^{\circ}$ $456-21 / 05 / 2012$
$30 / 11 / 2018$

Ordinance SAS/MS n ${ }^{\circ}$

$1.692-22 / 11 / 2016$

Joint Ordinance $\mathrm{n}^{\circ} 2$ 10/01/2018

Joint Ordinance $\mathrm{n}^{\circ} 1$ 29/05/2017

Joint Ordinance $\mathrm{n}^{\circ} 14$ 28/11/2017

Joint Ordinance $\mathrm{n}^{\circ} 4$ 22/06/2017

Joint Ordinance $\mathrm{n}^{\circ} 2$ $17 / 01 / 2020$
Joint Ordinance $\mathrm{n}^{\circ} 12$ 03/08/2020
Ordinance SAS/MS $\mathrm{n}^{\circ}$ $848-05 / 12 / 2011$
Joint Ordinance $n^{\circ} 09$ 27/03/2018

Source: Prepared by the authors based on data from the digital repositories of National Committee for Health Technology Incorporation (CONITEC) and Report on Prioritizing Guidelines for Comprehensive Care for People with Rare Diseases in Brazil 5 .

$\mathrm{a}=$ Secretariat of Health Care / Ministry of Health

$\mathrm{b}=$ Secretariat of Specialized Care / Secretariat of Science, Technology, and Strategic Inputs

c= Minister's Office / Ministry of Health

* Rare diseases for which drugs were recommended in the study period. 


\section{CLINICAL GUIDELINES}

\section{Sickle Cell Disease}

Ordinance SAS/MS n 55

- 29/01/2010
Joint Ordinance $\mathrm{n}^{\circ} 5$ -

19/02/2018
Hereditary and Acquired Epidermolysis Bullosa

Amyotrophic Lateral Sclerosis

Multiple Sclerosis

Systemic Sclerosis

Ankylosing Spondylitis

Phenylketonuria

Cystic Fibrosis

Paroxistic Nocturnal Hemoglobinuria*

Autoimmune Hepatitis

Congenital Adrenal Hyperplasia

Pulmonary Arterial Hypertension

Hypoparathyroidism

Congenital Hypothyroidism

Classical Homocystinuria*

Hereditary Ichthyosis

Primary Immunodeficiencies with

Antibody Deficiency

Addison's Disease

Exocrine Pancreatic Insufficiency

Systemic Lupus Erythematosus

Myasthenia Gravis
Ordinance SAS/MS n 0 $640-24 / 07 / 2014$

Ordinance SAS/MS $\mathrm{n}^{\circ}$ $712-17 / 12 / 2010$

Ordinance SAS/MS $\mathrm{n}^{\circ}$ $224-10 / 05 / 2010$
Joint Ordinance $\mathrm{n}^{\circ} 11$ 26/06/2020

Joint Ordinance $\mathrm{n}^{\circ} 13$ $13 / 08 / 2020$

Joint Ordinance $\mathrm{n}^{\circ} 7$ -

\section{3/07/2019 \\ Ordinance SAS/MS n $1505-29 / 12 / 2014$}

Joint Ordinance $\mathrm{n}^{\circ} 09$ 28/08/2017

Joint Ordinance $\mathrm{n}^{\circ} 25$ 22/10/2018

Joint Ordinance $\mathrm{n}^{\circ} 12$ 10/09/2019

Joint Ordinance $\mathrm{n}^{\circ} 8$ $15 / 08 / 2017$

Joint Ordinance SAES/SCTIE ${ }^{b}$ $n^{\circ} 18-20 / 11 / 2019$

Ordinance SAS/MS n $\quad$ Joint Ordinance $\mathrm{n}^{\circ} 14$ $457-21 / 05 / 2012 \quad 09 / 05 / 2018$

Ordinance SAS/MS n ${ }^{\circ} 16$

$-15 / 01 / 2010$

Ordinance SAS/MS no 35 Ordinance SAS/MS n 35

$-16 / 01 / 2014$

$-23 / 09 / 2014$

Ordinance SAS/MS n $14 \quad$ Ordinance SAS/MS n 450

$-15 / 01 / 2010$

- 29/04/2016

Ordinance SAS/MS n ${ }^{\circ} 56 \quad$ Ordinance SAS/MS n ${ }^{\circ}$ - 23/04/2010 $1.161-18 / 11 / 2015$

Joint Ordinance SAES/SCTIE $n^{\circ} 3-23 / 01 / 2020$

Ordinance SAS/MS n 13

$-15 / 01 / 2010$

Portaria SAS/MS n 1.162

$-18 / 11 / 2015$

Ordinance SAS/MS $\mathrm{n}^{\circ}$ $495-11 / 09 / 2007$

Ordinance SAS/MS n ${ }^{\circ} 15$

$-15 / 01 / 2010$

Joint Ordinance $\mathrm{n}^{\circ} 20$ $24 / 11 / 2020$

Ordinance SAS/MS n ${ }^{\circ} 57$ - 29/01/2010

Ordinance SAS/MS n 112

- 04/02/2016

Ordinance $\mathrm{GM} / \mathrm{MS}^{\mathrm{C}} \mathrm{n}^{\mathrm{O}}$ $100-07 / 02 / 2013$

$\begin{array}{ll}\text { Ordinance SAS/MS n } & \\ 229-10 / 05 / 2010 & \text { Ordinance SAS/MS n } \\ \end{array}$

Source: Prepared by the authors based on data from the digital repositories of National Committee for Health Technology Incorporation (CONITEC) and Report on Prioritizing Guidelines for Comprehensive Care for People with Rare Diseases in Brazil ${ }^{5}$.

$\mathrm{a}=$ Secretariat of Health Care / Ministry of Health

$\mathrm{b}=$ Secretariat of Specialized Care / Secretariat of Science, Technology, and Strategic Inputs

c= Minister's Office / Ministry of Health

* Rare diseases for which drugs were recommended in the study period. 


\section{CLINICAL GUIDELINES}

Mucopolysaccharidosis I* Joint Ordinance $\mathrm{n}^{\circ} 12$ $11 / 04 / 2018$

Mucopolysaccharidosis II* Joint Ordinance $\mathrm{n}^{\circ} 16$ 24/05/2018

Mucopolysaccharidosis IV A* Joint Ordinance SAS/SCTIE $\mathrm{n}^{\circ}$ $19-05 / 12 / 2019$

Mucopolysaccharidosis VI* Joint Ordinance SAS/SCTIE ${ }^{\circ}$ $20-05 / 12 / 2019$

Osteogenesis Imperfecta

Ordinance SAS/MS n ${ }^{\circ}$ $1306-22 / 11 / 2013$

Familial Amyloid Polyneuropathy* Joint Ordinance $\mathrm{n}^{\circ} 22$ Idiopathic Thrombocytopenic Purpura Ordinance SAS/MS $\mathrm{n}^{\circ}$ $1316-22 / 11 / 2013$ 02/10/2018

\begin{tabular}{|c|c|c|}
\hline & $1316-22 / 11 / 2013$ & $31 / 07 / 2019$ \\
\hline Guillain-Barré Syndrome & $\begin{array}{l}\text { Ordinance SAS/MS n }{ }^{\circ} 497 \\
-22 / 12 / 2009\end{array}$ & $\begin{array}{l}\text { Joint Ordinance n' } 15- \\
13 / 10 / 2020\end{array}$ \\
\hline Turner Syndrome & $\begin{array}{l}\text { Ordinance SAS/MS no } \\
223-10 / 05 / 2010\end{array}$ & $\begin{array}{l}\text { Joint Ordinance n' } 15- \\
\text { 09/05/2018 }\end{array}$ \\
\hline $\begin{array}{l}\text { Primary Nephrotic Syndrome in Children } \\
\text { and Adolescents }\end{array}$ & $\begin{array}{l}\text { Ordinance SAS/MS no } \\
459-21 / 05 / 2012\end{array}$ & $\begin{array}{l}\text { Joint Ordinance } n^{\circ} 1- \\
10 / 01 / 2018\end{array}$ \\
\hline
\end{tabular}

Non-infectious Uveitis * $459-21 / 05 / 2012 \quad 10 / 01 / 2018$

\section{TOTAL}

35

31

Joint Ordinance $\mathrm{n}^{\circ} 13-$ $11 / 09 / 2019$

16

Source: Prepared by the authors based on data from the digital repositories of National Committee for Health Technology Incorporation (CONITEC) and Report on Prioritizing Guidelines for Comprehensive Care for People with Rare Diseases in Brazil ${ }^{5}$.

$\mathrm{a}=$ Secretariat of Health Care / Ministry of Health

$\mathrm{b}=$ Secretariat of Specialized Care / Secretariat of Science, Technology, and Strategic Inputs

c= Minister's Office / Ministry of Health

* Rare diseases for which drugs were recommended in the study period.

For the 11 rare diseases for which there was no prior treatment available in the SUS and whose medicines were recommended during the study period (Table 5), it was identified that eight of them did not comply with the period established by law. Thus, the data obtained in this study were 292 days (median; $n=11$; minimum time=156 days; maximum time=351 days).

From the 32 incorporated medicines, the gathered data concerning the financing responsibility of 30 of them: 1 (3.33\%) referring to the Strategic Component of the Pharmaceutical Assistance; 24 (80\%) referring to group 1A of Specialized Component of the Pharmaceutical Assistance (CEAF); 3 (10\%) to group 1B and 2 (6.66\%) to group 2. For the following medicines: methionine-free metabolic formula (incorporated on 23/07/2019) and ivacaftor (incorporated on 31/12/2020), data were not available at the time of this study. 
When assessing the period required for the financial agreement, it was observed that in 15 situations, the timeframe did not comply with the law $^{18}$. The data obtained in this study were 193 days (median; $\mathrm{n}=24$; minimum time=10 days; maximum time=778 days). The maximum time observed was for tobramycin $300 \mathrm{mg} / 5 \mathrm{~mL}$ indicated for cystic fibrosis.

As for the national public medicines manufacturing, it was observed that, as of 2015 , some medicines for treating rare diseases were in the SUS list of strategic products, eligible for the Partnership for Productive Development (PDP) project proposal submissions. The partnerships in force in 2020 included treatments for multiple sclerosis (interferon beta-1a, fingolimod $0.5 \mathrm{mg}$, teriflunomide 14 mg); juvenile idiopathic arthritis (leflunomide $20 \mathrm{mg}$ ); juvenile idiopathic arthritis and ankylosing spondylitis (adalimumab $40 \mathrm{mg} / 0.8 \mathrm{~mL}$, certolizumab pegol 200 $\mathrm{mg} / \mathrm{mL}$, etanercept 25 and $50 \mathrm{mg} / \mathrm{mL}$, golimumab $50 \mathrm{mg}$, infliximab $10 \mathrm{mg} / \mathrm{mL}$, tocilizumab $20 \mathrm{mg} / \mathrm{mL}$ ); sickle cell anemia (hydroxyurea $500 \mathrm{mg}$ ); Crohn's disease (infliximab $10 \mathrm{mg} / \mathrm{mL}$ ); pulmonary arterial hypertension (sildenafil $20 \mathrm{mg}, 25 \mathrm{mg}, 50 \mathrm{mg}$ ); hemophilia (recombinant factor VIII); hypopituitarism and Turner syndrome (somatropin 4 IU and 12 IU); acromegaly (cabergoline 0.5 mg); Gaucher disease (taliglucerase alfa $200 \mathrm{UI}$ ); amyotrophic lateral sclerosis (riluzole $50 \mathrm{mg}$ ).

Table 5

The service offer was evaluated by identifying qualified reference centers after the promulgation of the PNAIPDR. By 2020, 19 Reference Services for Rare Diseases had been enabled in the country, according to the data described in Table 6.

Table 6

- Reference Services for Rare Diseases, Brazil, 2014-2020.

\begin{tabular}{|c|c|c|c|c|c|}
\hline Geographic Location & State & City & Initial jurisdiction & Axis $\mathrm{l}^{\mathrm{a}}$ & Axis $\|^{b}$ \\
\hline Midwest & Distrito Federal & Distrito Federal & $12 / 2016$ & $1,2,3$ & 1,3 \\
\hline Midwest & Distrito Federal & Distrito Federal & $12 / 2019$ & $1,2,3$ & $1,2,3$ \\
\hline Midwest & Goiás & Anápolis & $10 / 2016$ & $1,2,3$ & 1 \\
\hline Midwest & Minas Gerais & Belo Horizonte & $12 / 2019$ & $1,2,3$ & \\
\hline North East & Pernambuco & Recife & $10 / 2016$ & 1,3 & 1,2 \\
\hline North East & Bahia & Salvador & 07/2018 & $1,2,3$ & \\
\hline North East & Bahia & Salvador & $06 / 2019$ & $1,2,3$ & $1,2,3$ \\
\hline North East & Ceará & Fortaleza & $12 / 2019$ & $1,2,3$ & $1,2,3,4$ \\
\hline North East & Ceará & Fortaleza & $12 / 2019$ & $1,2,3$ & $1,2,3,4$ \\
\hline Southeast & Espírito Santo & Vitória & $12 / 2019$ & 1 & \\
\hline Southeast & Rio de Janeiro & Rio de Janeiro & $12 / 2016$ & $1,2,3$ & \\
\hline Southeast & São Paulo & Campinas & $12 / 2019$ & $1,2,3$ & \\
\hline Southeast & São Paulo & Santo André & $12 / 2016$ & 2,3 & 2,3 \\
\hline Southeast & São Paulo & Ribeirão Preto & $12 / 2019$ & $1,2,3$ & \\
\hline Southeast & São Paulo & Ribeirão Preto & $12 / 2020$ & $1,2,3$ & $1,2,3$ \\
\hline South & Paraná & Curitiba & $10 / 2016$ & $1,2,3$ & $1,2,3$ \\
\hline South & Paraná & Curitiba & $12 / 2020$ & 1 & \\
\hline South & Rio Grande do Sul & Porto Alegre & $12 / 2016$ & $1,2,3$ & \\
\hline South & Santa Catarina & Florianópolis & $12 / 2019$ & $1,2,3$ & $1,2,3$ \\
\hline
\end{tabular}

Axes according to PNAIDR:

Axis $\mathrm{I}^{\mathrm{a}}=$ Rare genetic diseases, with three groups: 1 - Congenital or late-onset anomalies, 2 - Intellectual disability, 3 - Inborn errors of metabolism. 
Axis II ${ }^{b}=$ Rare non-genetic diseases, with the following groups of causes: 1 - Infectious, 2 - Inflammatory, 3 - Autoimmune, 4 - Other rare nongenetic diseases.

Many medicines for treating rare diseases are listed on the Specialized Component of the Pharmaceutical Assistance (CEAF) strategy. In 2020, a change was identified in its execution model, increasing from three to six months the expiry period of the Report for the Request, Evaluation, and Authorization of Medicines from the Specialized Component of Pharmaceutical Assistance (LME).

Due to the Covid 19 pandemic, special criteria in the implementation of CEAF related to the documentation renewal and dispensing anticipation were advocated. Also, patients with Gaucher disease assisted by the MS, through the provision of enzymatic therapy by BioManguinhos/Fiocruz, started to be given the medicines infusion via home care service ${ }^{20}$.

Searches on the websites of the Legislative Power, social demands were identified in the scope of rare diseases, which were discussed in the Special Subcommittee on Rare Diseases of the Chamber of Deputies and in the Temporary Subcommittee on Rare Diseases of the Senate. Topics such as scientific research carried out in Brazil; incorporation of technologies by SUS considering specificities; expansion of diagnostic methods; defense of rights and social inclusion and improvement of specific legislation.

\section{Discussion}

The analysis model chosen in this study clearly shows that a set of interconnecting policies determines the access to medicines for treating rare diseases. Furthermore, the study showed that since the publication of the PNAIPDR, actions to promote access to such medicines are being developed in Brazil, including all phases of development, dispensation, and use of medicines. Although it is impossible to determine the explicit motivation of such actions concerning the PNAIPDR, its publication certainly was a landmark in Brazilian society, allowing greater recognition of the needs of rare diseases patients and the treatment's specificities. Therefore, expanding and guaranteeing access to pharmacological treatment is a fundamental demand to provide a better quality of life for people affected by a rare disease.

In the pre-launch activities, it was considered that the development of research for new medicines, the enlargement of financial resources forecast by the Federal Government, and the sanitary regulation of access to innovative treatments indicate that there are concrete initiatives to expand access. According to Gomes et al. ${ }^{21}$, aspects related to horizon scanning have positive repercussions as an informative tool for managers to risk reduction to the health system. Furthermore, the same authors ${ }^{21}$ mentioned that since the beginning of horizon scanning in Brazil, the most frequent themes of internal reports, alerts, summaries, and sections in the CONITEC recommendation reports were related to rare diseases. Another favorable factor is the ongoing epidemiological inquiry, for the data may help rationalize medicines based on a reliable national epidemiological forecast. However, despite the implementations mentioned above, it was impossible to identify a development line with long-term research, development, and innovation planning, which indicates the fragmentation of public policies and increasing external dependence. A similar finding was also previously described by Gadelha et al. ${ }^{22}$ in a study about Brazil's health economic-industrial complex.

In the peri-launch actions, different aspects can be considered drivers of access, such as regulating the sanitary registration of rare diseases medicines, which can expand the supply of new medicines in the SUS (Table 3). In this respect, ANVISA's RDC 204 and 205 may shorten the authorization period, as rare diseases medicines tend to meet the criteria for accelerated procedures based on an unmet need or disease severity. Nonetheless, Caetano et al. discussed that facing ANVISA prioritization analysis for rare diseases medicines; before 2018, the manufacturers could deliberately not apply for marketing authorization to profit with lawsuits, once the lack of sanitary register hinders setting a price for governmental sales as well as the CONITEC assessment. However, as for 20218, a register within ANVISA became mandatory due to Theme 106 judgment in the Supreme Court of Justice. Furthermore, it is noteworthy that the expansion of health records of medicines can expand the possibilities of prescription in the country. When there is no inclusion in the SUS payment table, accessibility often occurs through judicialization ${ }^{23}$.

There is a growing demand for incorporating rare diseases medicines (Table 4), both by SUS internal and external requests, as also described by Biglia et al. ${ }^{24}$. Despite the increasing demand for incorporations and growth in the public and patient involvement in the HTA process, the non-adoption of methodologies that consider broader approaches or values, in addition to cost-effectiveness, can be regarded as limiting access in the HTA settings for rare diseases ${ }^{12,26}$. Studies describe that standardized HTA methods may have limitations when assessing these medicines, as they may not accurately measure the social value of some health technologies ${ }^{10,12}$. Another limitation refers to issues related to pricing in Brazil. Some authors ${ }^{13}$ suggest that the pharmaceutical industries have been applying strategies to delay the launch of these medicines in lower-income countries due to the widespread use of international pricing policy ${ }^{13}$. When lacking reassessing on pricing or management contract, the growth of rare diseases medicines incorporation into the health system sparks off debates on the

Page $24 / 29$ 
right to health ${ }^{19}$. Caetano et al. ${ }^{27}$ also discussed conditional incorporation (ad experimentum) as a possibility for reassessing better technological alternatives based on evidence; however, the country does not have structural conditions for its successful development.

In post-launch interventions, the reassessment of norms related to good health practices and pharmacovigilance of medicines and updates to clinical guidelines and publications of new PCDT (Table 5) are important actions to promote the proper and efficient use of these medicines. Furthermore, the Reference Centers for Rare Disease (Table 6) accredited by MS, plus the incorporated molecular biology tests, cytogenetics, immunoassay, and genetic counseling, can expand diagnostic capability and the prospect of adequate treatment to the patient at the earliest opportunity. However, given many services, their geographic distribution in a continental country such as Brazil, and the value attributed to the cost and quantity of tests and genetic counseling offered, it is impossible to infer that the patients have guaranteed access.

Within the scope of national manufacturing, PDPs reduce the acquisition cost of medicines that are currently imported. They also boost local manufacture involving technology transfer to the Brazilian market ${ }^{29}$. Nevertheless, according to $\mathrm{D}^{\prime}$ Ippolito and $\mathrm{Gadelha}^{7}$, the national productive base has weaknesses that might contribute to a poorly inclusive development model ${ }^{7}$.

It was identified that logistical issues of pharmaceutical assistance remained unchanged. As already mentioned in previous studies ${ }^{15,30}$, the processes of planning, acquisition, distribution network improvement, and expansion of the Secretary of State for Health's role in promoting the rational use of medicines need broader discussions to avoid gaps in the patients' treatment.

The lack of alignment between the actions for medicines access implies the occurrence of judicialization. Consequently, it burdens the system and may restrict the support of health needs while not ensuring adequacy in the medicines administration, continuity of treatment, and follow-up by a trained health team besides favoring particular groups over others ${ }^{33}$.

According to Gammie et al. ${ }^{34}$, the national guidelines for rare diseases have a general purpose of creating a regulatory framework for access to services, treatment, information, encouragement of research, and patient advocacy. Still, often, they do not implement legislation for access to medicines. Legislation on orphan medicines in countries, such as the Orphan Drugs Act, passed in 1983 in the United States or Regulation (EC) No. 141/2000 in the European Union, could improve these medicines access, according to the authors ${ }^{34}$.

As a limitation of this study, it was considered that the material consulted do not present data related to the effective offer of medicines to patients, so future investigations on effective access are pertinent.

As final considerations, it is accepted that the enactment of PNAIPDR acknowledged the importance of discussing rare diseases in Brazil. The PNAIPDR also created a regulatory framework for service accessibility, increasing the demands for medicines incorporation, PCDT updates, and licensing of reference centers. However, these efforts were not aligned with care policies, pricing methods, technological development, and process management in pharmaceutical assistance lacking articulation in the care network. Consequently, there is no evidence that its publication has generated a broad impact on promoting access to medicines to treat rare diseases in Brazil. Furthermore, it is believed that the integration of medicines life cycle stages and usage cycle stages can improve the quality and speed of the processes, thus avoiding progressive losses in the quality of life of patients suffering from a rare disease, contributing to comprehensive care. Finally, it can also prevent the increase in judicialization related to medicines access.

\section{Abbreviations}

ALS: Amyotrophic Lateral Sclerosis

ANVISA: National Health Surveillance Agency

CEAF: Specialized Component of Pharmaceutical Assistance

CIT: Tripartite Interagency Commission

CNPq: National Council for Scientific and Technological Development

CONITEC: National Committee for Health Technology Incorporation

COPPE: Biomedical Engineering Program of the Alberto Luiz Coimbra Institute for Graduate Studies and Research in Engineering

Decit/SCTIE/MS: Department of Science and Technology of the Secretariat of Science, Technology, and Strategic Inputs of the Ministry of Health

Page 25/29 
HCN: Health Care Network

HTA: Health Technologies Assessment

Laif: Pharmacological Innovation Laboratory

LME: Report for the Request, Evaluation, and Authorization of Drugs from the Specialized Component of Pharmaceutical Assistance

MCDA Multicriteria Decision Analysis

MS: Ministry of Health

NICE: The National Institute for Health and Care Excellence

PCDT: Clinical Guidelines

PDP: Partnership for Productive Development

PNAIPDR: National Policy on Comprehensive Care of People with Rare Diseases

RDC: Collegiate Board Resolution

PROADI-SUS: Support Program for Institutional Development of the Brazilian Public Health System

ReBEC: Brazilian Registry of Clinical Trials

REBRATS: Brazilian Network for Health Technology Assessment

RENAME: Brazilian List of Essential Medicines

SUS: Unified Health System

Ufal: Federal University of Alagoas

UFRJ: Federal University of Rio de Janeiro

\section{Declarations}

Acknowledgement

The authors would like to thank the member of the Pharmaceutical Policies and Services Research Group from the Universidade Federal de Santa Catarina for their contribution to this study.

Funding

The research has no external funding sources.

Availability of data and materials

All data generated or analysed during this study are included in this published article.

Ethics approval and consent to participate

Not applicable. All the methods were in accordance with the relevant national/institutional/declaration of Helsinki in the manuscript please do the needful.

Competing interests

The authors declare that they have no competing interests.

Authors' contribution 
Conception and design: Cássia Cunico and Silvana Nair Leite; Writing of the article: Cássia Cunico; Relevant critical review of the intellectual content: Cássia Cunico, Geison Vicente and Silvana Nair Leite; Data analysis and interpretation: Cássia Cunico, Geison Vicente and Silvana Nair Leite. All authors approved the final version of the manuscript and are responsible for all aspects of the work in ensuring the accuracy and integrity of any part of the work.

Authors' information

Cássia Cunico: pharmacist at the Health Department of the State of Santa Catarina, in the Specialized Component of Pharmaceutical Services (CEAF). PhD student in the Postgraduate Program in Pharmaceutical Policy and Services, PPGASFAR, Universidade Federal de Santa Catarina (UFSC), with emphasis on rare diseases. Researcher of the Pharmaceutical Policies and Services Research Group at UFSC.

Geison Vicente: pharmacist at the Technical Support Centre of the Judiciary in the Health Department of Santa Catarina State. PhD student in the Postraduation Program in Pharmacy, UFSC, with emphasis on rare diseases. Researcher of the Pharmaceutical Policies and Services Research Group at UFSC.

Silvana Nair Leite: professor and researcher in the Postgraduate Program in Pharmaceutical Policy and Services, PPGASFAR at the Universidade Federal de Santa Catarina. Member of the Workforce Development HUB of the International Pharmaceutical Federation; Member of the sectorial Committee of the Nacional Health Council.

\section{References}

1. Richter T, Nestler-Parr S, Babela R, Khan ZM, Tesoro T, Molsen E, et al. International Society for Pharmacoeconomics and Outcomes Research Rare Disease Special Interest Group. Rare Disease Terminology and Definitions-A Systematic Global Review: Report of the ISPOR Rare Disease Special Interest Group. Value Health. 2015; 18(6):906-14. https://doi.org/10.1016/j.jval.2015.05.008

2. Nguengang Wakap S, Lambert DM, Olry A, Rodwell C, Gueydan C, Lanneau V, et al. Estimating cumulative point prevalence of rare diseases: analysis of the Orphanet database. Eur J Hum Genet. 2020; 28(2):165-173. https://doi.org/10.1038/s41431-019-0508-0

3. Brasil. Ministério da Saúde. Portaria n 199, de 30 de janeiro de 2014. Institui a Política Nacional de Atenção Integral às Pessoas com Doenças Raras, aprova as Diretrizes para Atenção Integral às Pessoas com Doenças Raras no âmbito do Sistema Único de Saúde (SUS) e institui incentivos financeiros de custeio. Diário Oficial da União, 2014; 31 Jan.

4. Interfarma. Associação da Indústria Farmacêuica de Pesquisa. Doenças Raras: A urgência do acesso à saúde. p.1-32, São Paulo, fev. 2018. https://www.interfarma.org.br/public/files/biblioteca/doencas-raras-a-urgencia-do-acesso-a-saude-interfarma.pdf. Accessed 20 Apr 2019.

5. Brasil. Comissão Nacional de Incorporação de Tecnologias no SUS. Relatório de Recomendação n 142: Priorização de protocolos e diretrizes terapêuticas para atenção integral às pessoas com doenças raras, mai. 2015.

http://conitec.gov.br/images/Relatorios/2015/Relatrio_PCDT_DoenasRaras_CP_FINAL_142_2015.pdf. Accessed 2 Mar 2020.

6. Melnikova, I. Rare diseases and orphan drugs. Nat Rev Drug Discov. 2012;

7. 30.;11(4):267-8. https://doi.org/10.1038/nrd3654

8. D'Ippolito PIMC, Gadelha CAG. 0 tratamento de doenças raras no Brasil: a judicialização e o Complexo Econômico-Industrial da Saúde. Saúde Debate. 2019; 43(n. especial 4): 219-231. https://doi.org/10.1590/0103-11042019S418

9. Rover MRM, Peláez CMV, Faraco EM, Farias MR, Leite NL. Avaliação da capacidade de gestão do componente especializado da assistência farmacêutica. Cien Saude Colet. 2017; 22(8):2487-2499. https://doi.org/10.1590/1413-81232017228.01602017

10. Giugliani L, Vanzella C, Zambrano MB, Donis KC, Wallau TKW, Costa FMD, et al. Clinical research challenges in rare genetic diseases in Brazil. Genet Mol Biol. 2019; 42(suppl 1):305-311. https://doi.org/10.1590/1678-4685-gmb-2018-0174

11. Araújo DV. Limitações dos métodos de ATS para decisão de incorporação de tecnologias para doenças raras. Jornal Brasileiro de Economia e Saúde. 2014; Supl.1:24-29.

12. Lima MAFD, Gilbert ACB, Horovitz DDG. Redes de tratamento e as associações de pacientes com doenças raras. Cien Saude Colet. 2018; 23(10):3247-56. https://doi.org/10.1590/1413-812320182310.14762018

13. Garrison LP, Jackson T, Paul D, Kenston M. Value-Based Pricing for Emerging Gene Therapies: The Economic Case for a Higher CostEffectiveness Threshold. J Manag Care Spec Pharm. 2019;25(7):793-799. https://www.jmcp.org/doi/10.18553/jmcp.2019.18378

14. Vogler S, Schneider P, Zimmermann N. Evolution of Average European Medicine Price: Implications for the Methodology of External Price Referencing. PharmacoEconomics-Open. 2019; 3:303-309. https://doi.org/10.1007/s41669-019-0120-9

Page $27 / 29$ 
15. Trevisan LM, Nalin T, Tonon T, Veiga LM, Vargas P, Krug BC et al. Access to treatment for phenylketonuria by judicial means in Rio Grande do Sul, Brazil. Cien Saude Colet. 2015; 20(5):1607-16. https://doi.org/10.1590/1413-81232015205.08302014

16. Brasil. Ministério da Saúde. Secretaria de Ciência, Tecnologia, Inovação e Insumos Estratégicos em Saúde. Departamento de Assistência Farmacêutica e Insumos Estratégicos. Coordenação-Geral do Componente Especializado da Assistência Farmacêutica. Ofício circular n 18/2020/CGCEAF/DAF/SCTIE/MS. Personal message: Cássia Cunico (Supervisão Regional de Saúde de São Miguel do Oeste, cunicoc@saude.sc.gov.br) 2020,29 jan.

17. World Health Organization - Regional Office for Europe. Access to new medicines in Europe: technical review of policy initiatives and opportunities for collaboration and research. World Health Organization, 2015.

18. Brasil. Ministério da Ciência, Tecnologia, Inovações e Comunicações. CNPq. Chamada CNPq/MS/SCTIE/DECIT No 25/2019 - Inquérito sobre perfil de doenças raras no Brasil. http://memoria2.cnpq.br/web/guest/chamadas-publicas?

p_p_id=resultadosportlet_WAR_resultadoscnpqportlet_INSTANCE_0ZaM\&filtro=encerradas\&buscaModo=textual\&tmp=1612541056161. Accessed 5 Feb 2021.

19. Brasil. Decreto 7.646, de 21 de dezembro de 2011. Dispõe sobre a Comissão Nacional de Incorporação de Tecnologias no Sistema Único de Saúde e sobre o processo administrativo para incorporação, exclusão e alteração de tecnologias em saúde pelo Sistema Único de Saúde - SUS, e dá outras providências. 2011. http://www.planalto.gov.br/CCIVIL_03/_Ato20112014/2011/Decreto/D7646.htm. Accessed 4 Apr 2020.

20. Ramos TM, Thomasi TZ, Duarte Júnior DP. Acordos de compartilhamento de riscos para aquisição do medicamento Spinraza ${ }^{\circledR}$ no Brasil: novas perspectivas sobre a proteção jurídica dos pacientes. Cad. Ibero-amer. Dir. Sanit. 2020; 9(2): 99-115. http://dx.doi.org/10.17566/ciads.v9i2.656

21. Brasil. Ministério da Saúde. Bio-Manguinhos. Notícias e Artigos. Alfataliglicerase: pacientes passam a ter home care durante a pandemia da COVID-19. https://www.bio.fiocruz.br/index.php/br/noticias/1788-alfataliglicerase-pacientes-passam-a-ter-home-caredurante-a-pandemia-da-covid-19. Accessed 1 May 2021.

22. Gomes PTCG, Mata VE, Borges TC, Galato D. Monitoramento do horizonte tecnológico no Brasil: produtos e repercussões. Rev Saude Publica. 2019; 53:111. https://doi.org/10.11606/S1518-8787.2019053001439

23. Gadelha, CAG; Costa, LS; Maldonado, J. O Complexo Econômico-Industrial da Saúde e a dimensão social e econômica do desenvolvimento. Rev Saúde Pública. 2012; 46(Supl):21-8.

24. Caetano R, Rodrigues PHA, Correa MCV, Villardi P, Osorio-de-Castro CGS. O caso do eculizumabe: judicialização e compras pelo Ministério da Saúde. Rev Saude Publica. 2020; 54:22. https://doi.org/10.11606/s1518-8787.2020054001693

25. Superior Tribunal de Justiça. Recurso Especial: REsp 1.657.156 - RJ (2017/0025629-7). https://stj.jusbrasil.com.br/jurisprudencia/574252474/recurso-especial-resp-1657156-rj-2017-0025629-7. Accessed 10 Aug 2021.

26. Biglia LV, Mendes SJ, Lima TM, Aguiar PM. Incorporações de medicamentos para doenças raras no Brasil: é possível acesso integral a estes pacientes? Cien Saude Colet [internet], 2020. http://www.cienciaesaudecoletiva.com.br/artigos/incorporacoes-de-medicamentospara-doencas-raras-no-brasil-e-possivel-acesso-integral-a-estes-pacientes/17706?id=17706\&id=17706\&id=17706. Accessed 12 Jan 2021.

27. Vicente G, Cunico C, Leite SN. Transformando incertezas em regulamentação legitimadora? As decisões das agências NICE e CONITEC para doenças raras. Cien Saude Colet. 2021. http://www.cienciaesaudecoletiva.com.br/artigos/transformando-incertezas-emregulamentacao-legitimadora-as-decisoes-das-agencias-nice-e-conitec-para-doencas-raras/17976?id=17976\&id=17976

28. Caetano R, Hauegen RC, Osorio-de-Castro CGS. A incorporação do nusinersena no Sistema Único de Saúde: uma reflexão crítica sobre a institucionalização da avaliação de tecnologias em saúde no Brasil. Cad. Saúde Pública. 2019; 35(8).https://doi.org/10.1590/0102$311 \times 00099619$

29. Brasil. Ministério da Saúde. Portaria n 3.166, de 03 de dezembro de 2019. Habilita estabelecimentos de saúde como Serviço de Referência em Doenças Raras e estabelece recurso do Bloco de Custeio das Ações e Serviços Públicos de Saúde da Atenção de Média e Alta Complexidade Ambulatorial e Hospitalar - Grupo de Atenção de Média e Alta Complexidade - MAC, a ser disponibilizado por meio do Fundo de Ações Estratégicas e Compensação - FAEC aos Estados e Municípios. Diário Oficial da União, $2019 ; 04$ Dez.

30. Brasil. Ministério da Saúde. Assuntos. Parcerias para o Desenvolvimento Produtivo. https://www.gov.br/saude/pt-br/assuntos/saudede-a-a-z-1/p/parcerias-para-o-desenvolvimento-produtivo-pdp. Accessed 10 May 2021.

31. Rover MRM, Faraco EB, Vargaz-Peláez CM, Colussi C, Storpirits S., Farias M, Leite SN. Acesso a medicamentos de alto preço: Desigualdades na organização e resultados entre estados brasileiros. Cien Saude Colet. http://www.cienciaesaudecoletiva.com.br/artigos/acesso-a-medicamentos-de-alto-preco-desigualdades-na-organizacao-e-resultadosentre-estados-brasileiros/17707?id=1770

Page 28/29 
32. Colpani V, Kowalski SC, Stein AT, Buehler AM, Zanetti D, Côrtes G, et al. Clinical practice guidelines in Brazil - developing a national program. Health Res Policy Syst. 2020; 18:69. https://doi.org/10.1186/s12961-020-00582-0

33. Piret CNS, Medeiros CRO. Doenças Raras, Medicamentos Órfãos: reflexões sobre o dark side das organizações da indústria farmacêutica. Revista Brasileira de Estudos Organizacionais. 2018; 4(2):437-460.

34. Lopes MT, Koch VH, Sarrubi-Junior V, Galo PR, Carneiro-Sampaio MC. Difficulties in the diagnosis and treatment of rare diseases according to the perceptions of patients, relatives, and health care professionals. Clinics. 2018; 73 :e68.

https://doi.org/10.6061/clinics/2018/e68

35. Gammie T, Lu CY, Babar ZUD. Access to orphan drugs: A comprehensive review of legislations, regulations and policies in 35 countries. PLoS ONE. 2015; 10(10):1-24, 2015. https://doi.org/10.1371/journal.pone.0140002 